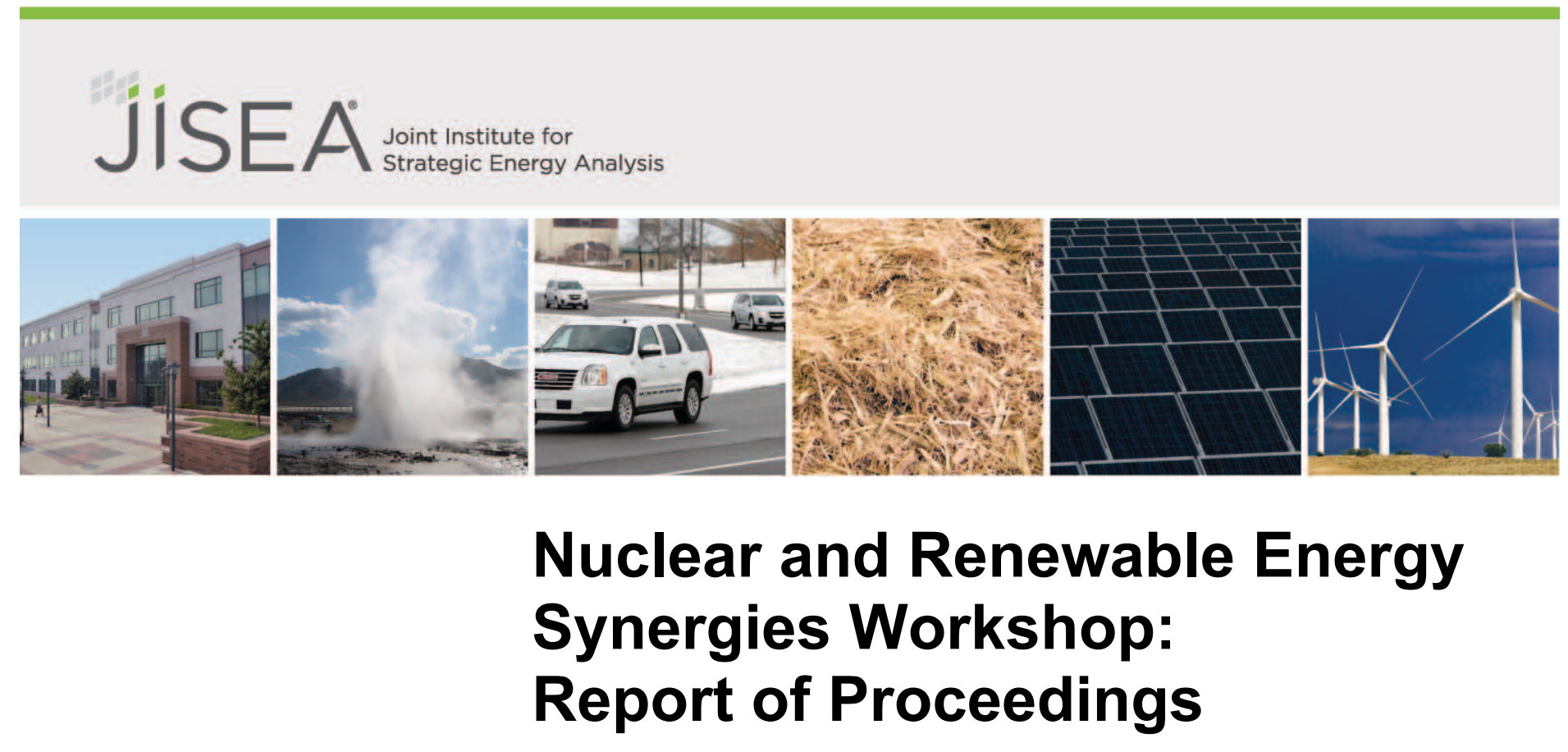

Mark Ruth, Mark Antkowiak, and Scott Gossett

The Joint Institute for Strategic Energy Analysis is operated by the Alliance for Sustainable Energy, LLC, on behalf of the U.S. Department of Energy's National Renewable Energy Laboratory, the University of Colorado-Boulder, the Colorado School of Mines, the Colorado State University, the Massachusetts Institute of Technology, and Stanford University.

Technical Report

NREL/TP-6A30-52256

December 2011 


\title{
Nuclear and Renewable Energy Synergies Workshop: Report of Proceedings
}

\author{
Mark Ruth, Mark Antkowiak, and Scott Gossett
}

Prepared under Task No. 6A30.2003

The Joint Institute for Strategic Energy Analysis is operated by the Alliance for Sustainable Energy, LLC, on behalf of the U.S. Department of Energy's National Renewable Energy Laboratory, the University of Colorado-Boulder, the Colorado School of Mines, the Colorado State University, the Massachusetts Institute of Technology, and Stanford University.

JISEA $^{\circledR}$ and all JISEA-based marks are trademarks or registered trademarks of the Alliance for Sustainable Energy, LLC.

The Joint Institute for Strategic Energy Analysis 1617 Cole Boulevard Golden, Colorado 80401 303-275-3000 • www.jisea.org
Technical Report

NREL/TP-6A30-52256

December 2011

Contract No. DE-AC36-08G028308 


\section{NOTICE}

This report was prepared as an account of work sponsored by an agency of the United States government. Neither the United States government nor any agency thereof, nor any of their employees, makes any warranty, express or implied, or assumes any legal liability or responsibility for the accuracy, completeness, or usefulness of any information, apparatus, product, or process disclosed, or represents that its use would not infringe privately owned rights. Reference herein to any specific commercial product, process, or service by trade name, trademark, manufacturer, or otherwise does not necessarily constitute or imply its endorsement, recommendation, or favoring by the United States government or any agency thereof. The views and opinions of authors expressed herein do not necessarily state or reflect those of the United States government or any agency thereof.

Available electronically at http://www.osti.gov/bridge

Available for a processing fee to U.S. Department of Energy and its contractors, in paper, from:

U.S. Department of Energy

Office of Scientific and Technical Information

P.O. Box 62

Oak Ridge, TN 37831-0062

phone: 865.576 .8401

fax: 865.576 .5728

email: mailto:reports@adonis.osti.gov

Available for sale to the public, in paper, from:

U.S. Department of Commerce National Technical Information Service 5285 Port Royal Road Springfield, VA 22161 phone: 800.553 .6847 fax: 703.605.6900

email: orders@ntis.fedworld.gov

online ordering: http://www.ntis.gov/help/ordermethods.aspx

Cover Photos: (left to right) PIX 12721, PIX 13995, @ GM Corp., PIX 16161, PIX 15539, PIX 16701

Printed on paper containing at least $50 \%$ wastepaper, including $10 \%$ post consumer waste. 


\section{Acknowledgments}

The authors would like to thank all who contributed their time and insights to make the Nuclear and Renewable Energy Synergies Workshop successful. Without them, the ideas and information in this report would not exist. The authors would also like to thank several individuals who made this workshop and this resulting report possible. Doug Arent and Patricia Statwick of the Joint Institute for Strategic Energy Analysis (JISEA) and Robin Newmark, Paul Denholm, Mike Helwig, Jeff Bedard, and Bob Westby of the National Renewable Energy Laboratory (NREL) applied their considerable knowledge and capabilities to focus the workshop's goals, identify potential attendees, organize the workshop, and assist in pulling together the resulting documents. Dana Bryson, Doug Mcghee, and Lois Todd-Lynch of Alchemy facilitated the discussion. Patricia Statwick, Dani Salyer, and Pamela Lee-Bull of JISEA contributed to a smoothly run event and to capturing the contributions to this dialog. Finally, we would like to thank the U.S. Department of Energy for partially funding the work contained in this report. 


\section{List of Acronyms}

AP- 1000

APWR

CCGT

COL

CSP

DOD

DOE

EERE

EIA

EPR

ESBWR

FCEV

GHG

GWe

HTE

IEA

INL

JISEA

$\mathrm{kWh}$

LCOE

LWR

MWe

NIMBY

NRC

NREL

OECD

O\&M

PV

R\&D

SMR

VG advanced pressurized water reactor (Westinghouse design)

advanced pressurized water reactor (Mitsubishi design)

combined cycle gas turbine

combined license

concentrating solar power

U.S. Department of Defense

U.S. Department of Energy

U.S. Department of Energy's Office of Energy

Efficiency and Renewable Energy

Energy Information Administration

European pressurized reactor

economic safe boiling water reactor

fuel cell electric vehicle

greenhouse gas

gigawatt of electricity

high temperature electrolysis

International Energy Agency

Idaho National Laboratory

Joint Institute for Strategic Energy Analysis

kilowatt hours

levelized cost of energy

light water reactor

megawatt of electricity

not in my back yard

U.S. Nuclear Regulatory Commission

National Renewable Energy Laboratory

Organization for Economic Cooperation and

Development

operations and maintenance

solar photovoltaic

research and development

small modular reactor

variable generation 


\section{Executive Summary}

Two of the major challenges the U.S. energy sector faces are greenhouse gas emissions and oil that is both imported and potentially reaching a peak (the point at which maximum extraction is reached). Interest in development of both renewable and nuclear energy has been strong because both have potential for overcoming these challenges. Each has the potential to de-carbonize the energy sector, and electricity, biofuels, and hydrogen from renewable and nuclear sources have the potential to replace oil used for transportation.

Research in both energy sources is ongoing, but relatively little research has focused on the potential benefits of combining nuclear and renewable energy. In September 2011, the Joint Institute for Strategic Energy Analysis (JISEA) convened the Nuclear and Renewable Energy Synergies Workshop at the U.S. Department of Energy's National Renewable Energy Laboratory (NREL) to identify potential synergies and strategic leveraging opportunities between nuclear energy and renewable energy. Industry, government, and academic thought leaders gathered to identify potential broad categories of synergies and brainstorm topic areas for additional analysis and research and development (R\&D). This report records the proceedings and outcomes of the workshop.

Section 1 provides an introduction to the challenges facing the U.S. energy sector and a look at the recent history of both nuclear and renewable energy use in this country.

Section 2 summarizes a series of presentations that set the stage for group discussion.

Section 3 focuses on the process of determining the high impact categories of synergies between nuclear and renewable energy and defining critical next steps for each. The workshop participants identified nine broad categories of synergies: balancing capacity on the grid; islandable micro-grids and small modular reactors (SMRs); energy for transportation; energy for industrial applications; hybrid energy systems; lessons learned; permitting, licensing, and financing; business model development; and policy and institutional opportunities.

The participants prioritized two technical categories - energy for transportation and hybrid energy systems - and one institutional category — business model development — as having the greatest potential for high impact, which was defined as a balance between scale of the issues or opportunities, probability of success, near-term potential, complexity, cost, and ability to move to implementation. In the two technical categories, workshop participants identified high priority analysis and R\&D needs. Those needs include development of a list of requirements, dynamic system models, process designs, cost and scale analysis, R\&D on enabling technologies, R\&D on components, and process integration. In the institutional category, workshop participants identified motivating drivers for and challenges to the development of business cases. Motivating drivers ranged from societal motivation, such as sustainability and economic and national security, to near-term needs, such as a vision and roadmap that define the problem being solved and a path toward the solution.

Section 4, conclusions, identifies opportunity to channel interest in this topic toward advancing understanding of nuclear and renewable energy synergies. 


\section{Table of Contents}

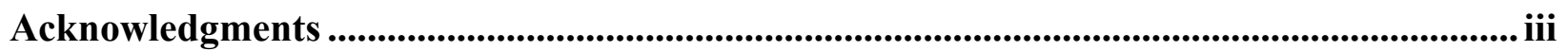

List of Acronyms .................................................................................................................................. iv

Executive Summary ............................................................................................................................ $\mathrm{v}$

Table of Contents ................................................................................................................................... vii

List of Figures.................................................................................................................................... viii

List of Tables ........................................................................................................................................ viii

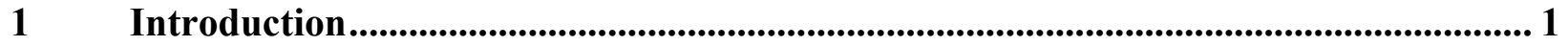

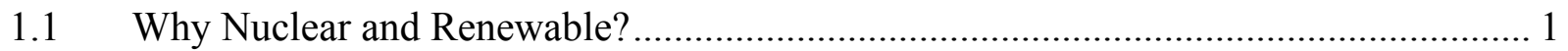

1.2 Research Program Structure and Alignment with JISEA Strategies …………............... 2

2 Workshop Proceedings, Part 1: Setting the Stage ................................................................. 4

$2.1 \quad$ U.S. Nuclear Power Policies and R\&D Programs ......................................................... 4

2.2 Nuclear/Wind/Hydrogen Systems for Variable Electricity and Hydrogen Production

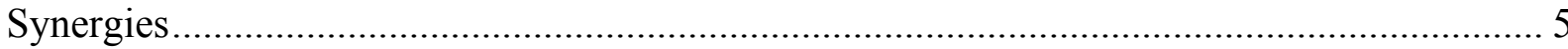

2.3 The Potential Role of Thermal Energy Storage .......................................................... 7

2.4 Southeast Defense Energy Initiative and the U.S. Energy Freedom Center ${ }^{\mathrm{TM}}$.............. 10

2.5 Small Reactors for Energy Supply: Islanded Generation and Load Management ........ 11

2.6 Grid Scale Hybrid Energy System: Integrating Renewable and Nuclear Power.......... 13

2.7 Non-Technical Considerations for Small Modular Reactors......................................... 14

2.8 Small Modular Reactors_-NRC Readiness for Licensing Reviews............................ 16

$3 \quad$ Workshop Proceedings, Part 2: Identifying Synergies................................................... 18

$3.1 \quad$ Nuclear/RE Synergy: Energy for Transportation ...................................................... 20

$3.2 \quad$ Nuclear/RE Synergy: Hybrid Energy Systems ........................................................... 22

3.3 Nuclear/RE Synergy: Business Model Development .................................................. 23

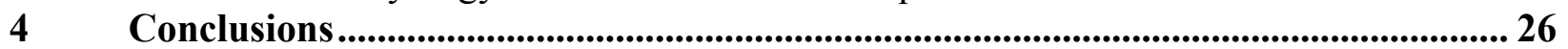

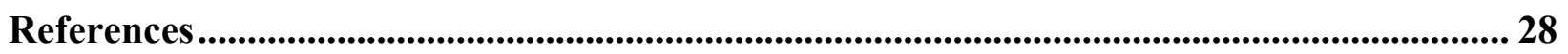

Appendix A: Workshop Participants.................................................................................... 31

Appendix B: Workshop Agenda................................................................................... 32

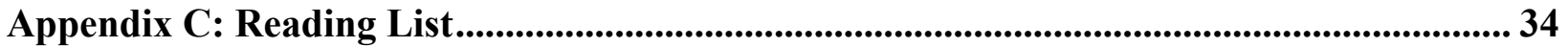




\section{List of Figures}

Figure 1. Model for hybrid nuclear/renewable/hydrogen system .......................................... 6

Figure 2. Power generation over time by source in hybrid energy system............................... 7

Figure 3. Incremental capacity factor and LCOE multiplier of nuclear achieving de-carbonized

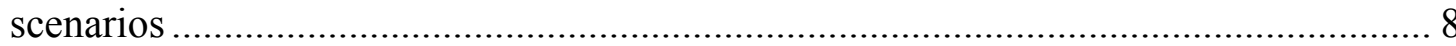

Figure 4. Nuclear fleet capacity factors in various high renewable penetration scenarios........... 9

Figure 5. SMR/natural gas/renewable power hybrid system .......................................... 13

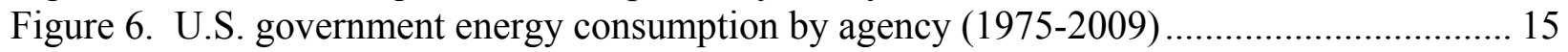

\section{List of Tables}

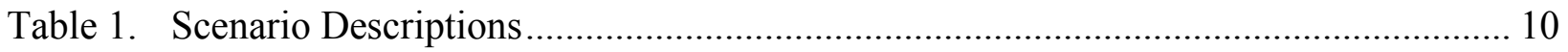

Table 2. Value Propositions for Partners in Southeast Defense Energy Initiative ................... 11 


\section{Introduction}

\subsection{Why Nuclear and Renewable?}

Two of the major challenges the U.S. energy sector faces are greenhouse gas (GHG) emissions and oil that is both predominately imported (EIA, September 2011) and potentially reaching a peak - the point at which maximum extraction is reached (Appenzeller, 2004). Historically, interest in development of both renewable and nuclear energy has been strong because both have potential for overcoming the first of the challenges - decarbonizing the energy sector. In the United States, the Obama administration has pledged to reduce greenhouse gas emissions 17\% below 2005 levels by 2020. With today's technology, hitting such targets will require large increases in low-carbon and zero-carbon energy generation like nuclear and renewables.

Historically, renewable and nuclear energy sources have been treated indepedently as feasible, low carbon energy sources because each has strengths and weaknesses. However, potential synergies between nuclear and renewable energy, largely unexplored, may exist and amplify the potential for each of these power sources. Integrating nuclear energy and renewable energy systems may lead to additional and better options for meeting energy needs and energy policy goals.

Prior to the 2011 Fukushima, Japan, nuclear plant catastrophe, worldwide interest had been growing in nuclear power as a viable low carbon option for electricity generation. Among all countries in the Organization for Economic Cooperation and Development (OECD), the share of total primary energy supply provided by nuclear rose from $1.3 \%$ in 1973 to $11.3 \%$ in 2009 (International Energy Agency 2010). In August 2011, Europe had 187 nuclear power plant units in operation and another 19 under construction in six countries, for a total installed and planned capacity of 178.9 GWe (European Nuclear Society 2011).

In the past 30 years, nuclear power generation in the United States grew from 250 billion $\mathrm{kWh}$ to 800 billion $\mathrm{kWh}$ which represents growth from $11.0 \%$ of total net generation in 1980 to $20.2 \%$ in 2009 (Energy Information Administration 2011). The EIA also projects that nuclear energy generation will grow during the next 15 years (EIA Annual Energy Outlook 2011).

Japan was pursuing a multi-decade plan to provide $50 \%$ of its electricity from nuclear power (Scheer and Moss 2011). However, the earthquake and tsunami that damaged the Fukushima plant in 2011 sparked not only a examination of the future of nuclear power in Japan but also a global reassessment of nuclear safety. China has announced delays in its nuclear build out. The United States is undertaking a comprehensive reassessment of risks for the U.S. nuclear fleet. Germany is phasing out and closing all 17 of its reactors with 8 shut down immediately (World Nuclear Association, 2011).

Additionally, other concerns are challenges related to the expansion of the nuclear industry. At this time, the United States does not have a location or plan for disposal of nuclear waste (GAO11-229 April 2011). Financial requirements for large scale nuclear plants remain a significant challenge. U.S. utilities, in particular, are reluctant to commit to a nuclear plant's multibillion dollar cost without risk managed structures (Indiviglio 2011). Water requirements are also causing concerns (Lochbaum 2007). 
Renewable electricity use is also growing. Renewable energy provided $10 \%$, or 425 billion kilowatthours (kWh) of electricity in the United States in 2010, which represented a 4\% increase over 2009 (IEA 2011). Worldwide, renewable (excluding hydropower) electricity generation doubled between 2000 and 2009, from $1.9 \%$ to $3.8 \%$ (EERE 2009).

But the renewable electricity sector faces its own challenges. Variable generation (VG) resources, such as solar and wind power, affect grid management and change the operational economics of the power system. Variable resources require a flexible grid and, above certain penetration levels for a defined balancing area, storage options to match power supply to times of power demand. Renewable electricity generation also has siting issues because technologies such as wind and solar need to be sited where land where the energy resource is abundant. Those locations are often not near demand so additional transmission infrastructure is necessary.

Decarbonization of the energy sector is only the first of the challenges that needs to be overcome. The second challenge, reducing imported oil and decarbonization of transportation, is as important but has been outside most of the discussions for uses of nuclear energy. The two exceptions are the naval fleet and hydrogen vehicles. For example, during the past 10 years, hydrogen has been investigated as an energy carrier that could be used for light-duty, fuel cell electric vehicles (FCEVs). The necessary hydrogen could be produced from fossil, nuclear, and renewable resources. Renewable energy $R \& D$ for fuels has also focused on biofuels that can be used in vehicles with internal combustion engines or jet engines.

Relatively little research has focused on the potential benefits of combining nuclear and renewable energy. However, synergies do exist. Specific opportunities include balancing capacity on the grid, islanded sites, integrated uses of non-electrical products from nuclear reactors (including hydrogen and heat), and component technologies that might be used by both systems. Additional opportunities were identified during the workshop.

\subsection{Research Program Structure and Alignment with JISEA Strategies}

In September 2011, the Joint Institute for Strategic Energy Analysis (JISEA) convened the Nuclear and Renewable Energy Synergies Workshop at the U.S. Department of Energy's National Renewable Energy Laboratory (NREL) to identify strategic leveraging opportunities and synergies between development and implementation of nuclear energy and renewable energy.

JISEA gathered 40 thought leaders from industry, government, and academia to identify and prioritize topic areas for potential synergies. On the second day of the workshop, participants formed smaller groups, each of which focused on one of the prioritized topic areas. Through facilitated discussions and brainstorming sessions, each group identified specific synergies in its focus area as well as analysis necessary to determine the potential value of the synergies and research and development (R\&D) needed to bring them to practice.

The discussion of nuclear and renewable energy is a natural fit for JISEA, an organization founded to move global energy systems toward a sustainable future through transdisciplinary development of objective and credible data, tools, and analysis that inform the energy dialogue and guide energy investment and policy decisions. JISEA has already funded exploratory analysis examining potential synergies of nuclear and renewable energy, as well as an 
exploration of the synergies of natural gas, nuclear, and renewable electricity in the U.S. power system, and future areas of study include transportation, industrial, and commercial energy systems, and sustainable urban environments.

The workshop discussion was framed by JISEA Executive Director Doug Arent within a definition of sustainable solutions - those that meet the needs of the present without compromising the ability of future generations to meet their own needs (Our Common Future 1987) — and a global context: 2012 is the International Year of Sustainable Energy for All. The United Nations-sponsored event seeks to highlight the importance of sustainable energy systems for global economic development and achieving other of the body's millennium development goals. 


\section{Workshop Proceedings, Part 1: Setting the Stage}

The workshop began with a series of presentations by government, business, and academic leaders designed to prime the pump of dialogue and promote exchange of ideas. Sections 2.1-2.7 summarize those reports.

\subsection{U.S. Nuclear Power Policies and R\&D Programs}

Peter Lyons, Assistant Secretary for Nuclear Energy at the U.S. Department of Energy (DOE), kicked off the workshop with a discussion of the vision for nuclear energy in U.S. energy policy (Lyons 2011). DOE sees nuclear power as an essential component of the U.S. energy mix, and one that must grow to meet national goals for clean energy, economic prosperity, and national security. The primary mission of DOE's Office of Nuclear Energy is to advance nuclear power as a resource capable of making major contributions in meeting the nation's energy supply, environmental, and energy security needs by resolving technical, cost, safety, security and regulatory issues, through research, development, and demonstration. DOE is focusing on developing and deploying fission power systems for production of both electricity and process heat. Lyons sees renewed interest in nuclear energy:

- Eighteen construction and operating license applications for 28 new reactors have been submitted for U.S. Nuclear Regulatory Commission (NRC) review

- DOE has certified four new reactor designs and has three new designs (APWR, EPR, and ESBWR) and one amendment (AP-1000) under review

- Four plant construction contracts have been initiated and nine power companies have placed forging orders for large components.

Lyons sees this renewed interest as a part of the President's portfolio focus to meet the clean energy objectives he stated in the 2011 State of the Union address:

“This is our generation's Sputnik moment. ... We'll invest in biomedical research, information technology, and especially clean energy technology-an investment that will strengthen our security, protect our planet, and create countless new jobs for our people.

"So tonight, I challenge you to join me in setting a new goal: By 2035, 80\% of America's electricity will come from clean energy sources. Some folks want wind and solar. Others want nuclear, clean coal, and natural gas. To meet this goal, we will need them all..."

President Barack Obama

January 25, 2011

To support this renewed interest in nuclear power, the administration is offering new financial incentives and has requested \$67M in FY12 to support licensing and deployment of small modular reactors (SMRs).

Setting the stage for a discussion that would focus on innovative approaches to nuclear energy, Lyons recognized that while interest in nuclear power is evident, large scale reactors still face significant political and financial obstacles. In the wake of the Fukushima plant accident, he 
described renewed efforts to ensure the safety of U.S. nuclear facilities, including several priorities for R\&D work going forward:

- Developing passive safety systems that reduce the need for electronic feedback or operator actions in order to shut down the reactor;

- Advancing understanding of dry cask storage systems;

- Re-engineering fuel containment barriers, including enhancing the mechanical strength of silicon carbide fuel cladding, to reduce complications;

- Re-evaluating potential natural phenomena, including seismic activity; and

- Targeting use of modeling and simulation for performance of current and future reactors.

\subsection{Nuclear/Wind/Hydrogen Systems for Variable Electricity and Hydrogen Production Synergies}

In a presentation that shaped much of the dialog in the workshop, Charles Forsberg of the Massachusetts Institute of Technology built the case for a hybrid energy system of nuclear, wind, and hydrogen by describing the energy market and its requirements (Forsberg 2011). Forsberg outlined two long-term markets in the United States: electricity and hydrogen. The United States consumes 9 million tons of hydrogen per year to fuel industrial and chemical processes like converting heavy oil and biomass into gasoline and diesel; removing sulfur from liquid fuels; producing fertilizer (ammonia); and converting metal ores to metal. Forsberg stated that the hydrogen market is growing and future uses of hydrogen could include production of peak electricity and direct use as a transportation fuel in fuel cell electric vehicles (FCEVs).

Forsberg described key characteristics of the electricity market to build the case for solutions that address the needs of both the electricity and hydrogen markets. Electricity demand is variable: two-thirds is a constant, or baseload, demand, but the demand tends to peak seasonally (in summer and winter), weekly (during the work week), and daily (during daytime hours). Peak electricity is very expensive because of the capital investment in systems that do not run at full capacity but are instead only needed during peak demand. Today, those systems are mostly fossil fuel-based and have relatively low capital costs. They are usually gas turbines. Renewables could be used to provide peak power, but only if production matches peak demand or the energy is stored. Present storage technology is not sufficiently economic to smooth out the peaks of production. Long-term storage is currently expensive and, at 50\% efficiency, inefficient.

Given this picture of the energy market, Forsberg described a scenario in which hydrogen could enable economically viable nuclear-renewable energy systems by taking advantage of the duality of hydrogen (it can be used for both industrial purposes and to produce electricity). For Forsberg, the challenge is that capital-intensive nuclear, solar, or wind facilities must run at capacity to maximize economic performance. He proposed using excess electricity (when demand is low) to produce hydrogen that will fulfill growing demand for it. 


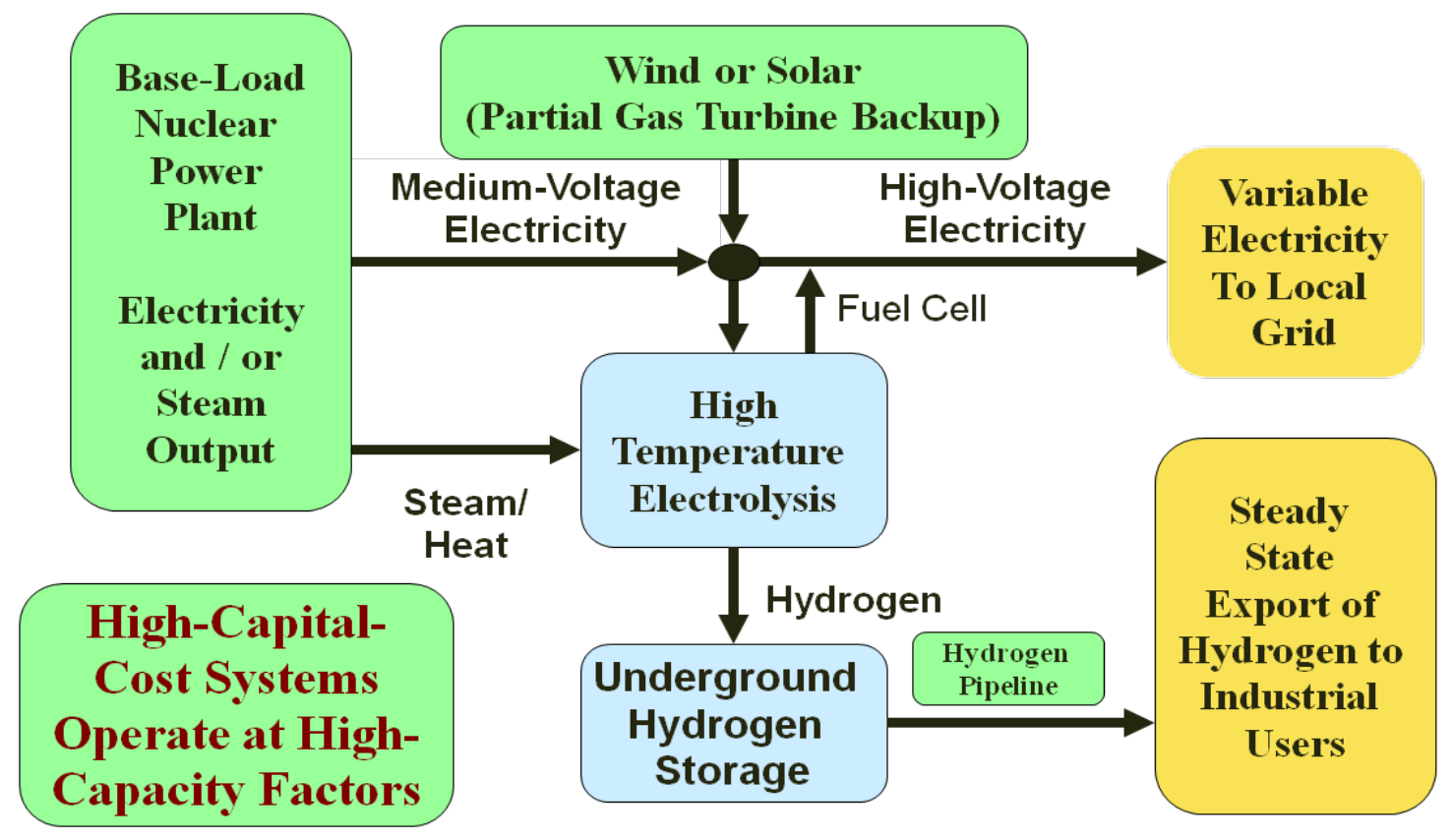

Figure 1. Model for hybrid nuclear/renewable/hydrogen system

Source: Forsberg (2011b)

Forsberg's research group tested his proposal with an analysis of potential on the Midwest grid (average 61.8 GWe, peak 96.5 GWe, and minimum $39.5 \mathrm{GWe}$ ), North Dakota wind, and a nuclear, wind, natural gas, hydrogen system as shown in Figure 1. His analysis uses light water reactors and high temperature electrolysis (HTE) to produce variable amounts of electricity and hydrogen. He stated that HTE is the critical technology. It uses cheap heat from nuclear process to replace expensive electricity in the production of hydrogen. During periods of high electricity demand, the system is designed to flow in reverse, acting as a fuel cell to create electricity. Operating HTE in reverse as fuel cells replaces peaking gas turbines that operate only tens to hundreds of hours per year - partly paying for the capital costs of HTE units. The sale of storable hydrogen as a second independent product provides a market for "excess" electricity at times of high wind production and low electricity demand that (1) allows higher utilization of wind resources and (2) minimizes costly inefficient conversion of electricity to stored hydrogen and back to electricity. Hydrogen for electricity production is limited to times of peak demand where the capital cost savings by eliminating gas turbines with low capacity is more important than the operating cost of using hydrogen as a fuel. The relative contribution of nuclear and wind is dependent upon relative production costs and the need to minimize expensive electricity storage as hydrogen (or other technologies) to meet peak electricity demand.

Example results from analyses performed by Forsberg's group are shown in Figure 2. The figure shows that nuclear energy fills the baseload and wind electricity fills many of the peaks. Additional power is provided from the fuel cell and a combined cycle gas turbine (CCGT). Their analysis over a sample year indicated that nuclear generation provides $58.6 \%$ of the total power required with wind, hybrid nuclear, CCGT, and reversible fuel cells providing $25.9 \%, 3.7 \%$, $11.3 \%$, and $0.5 \%$, respectively. Forsberg also stated that the system economics work if largescale facilities can be coupled with large low-cost hydrogen pipelines, storage, and related facilities. 


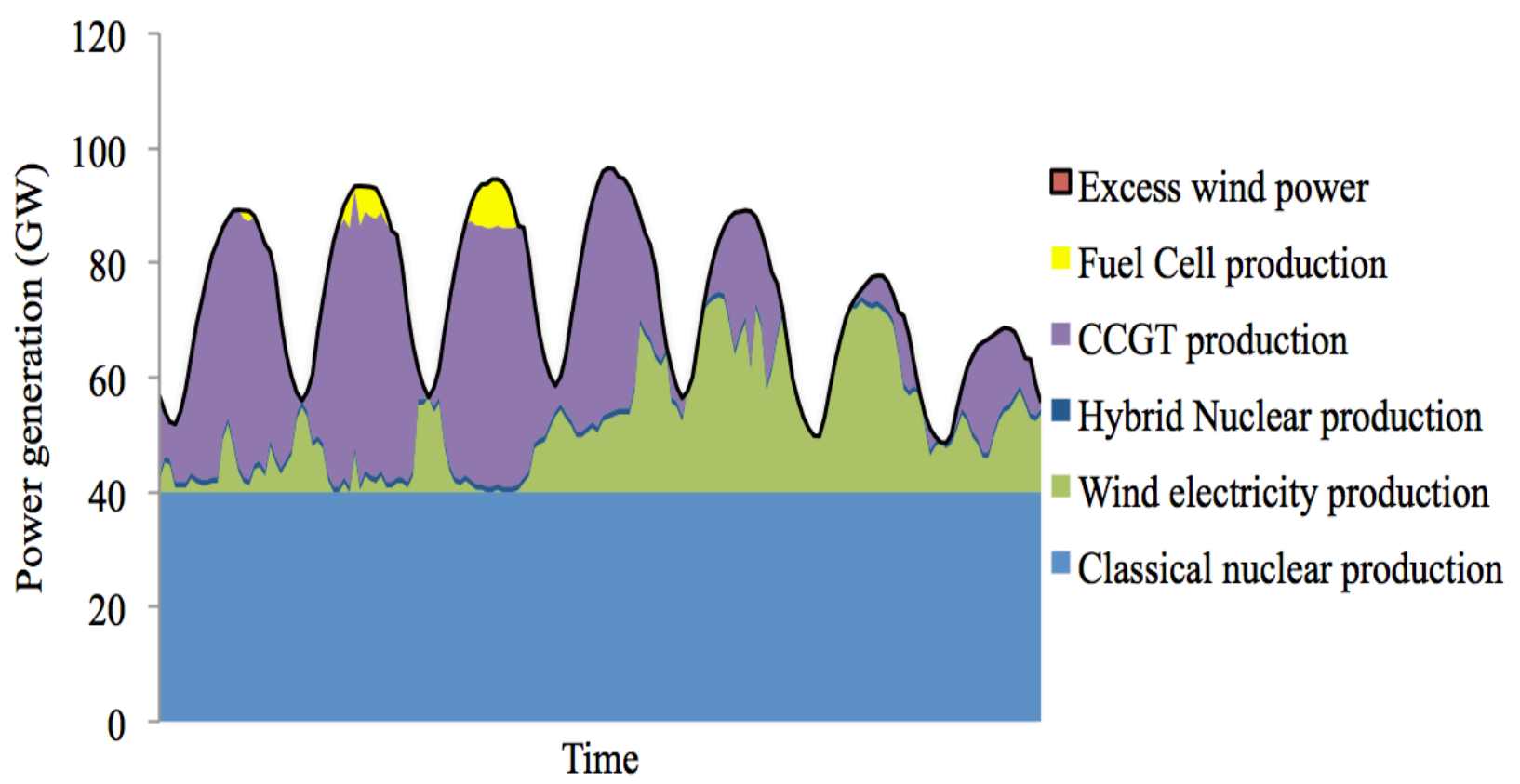

Figure 2. Hourly simulation of power generation over a sample week in hybrid energy system

Source: Forsberg (2011b)

\subsection{The Potential Role of Thermal Energy Storage}

In an effort to de-carbonize the energy sector and achieve other goals, renewable resources like wind and solar are being integrated into the grid. . At sufficient penetration levels, the net load becomes more variable and the balance of the system (e.g., traditional baseload plants) will need to ramp and cycle more frequently. Increased ramping and cycling will reduce demand for baseload systems that are nominally designed to provide constant output; however, the economic viability of baseload plants, like nuclear reactors, depends on constant and predictable output. NREL's Paul Denholm presented a nuclear / thermal storage / renewable system concept as one possible option to economically optimize nuclear-renewable power generation. The additional of thermal storage to a high temperature nuclear facility, in combination with an oversized power block, allows thermal-electric power plants to achieve capacity factors for heat production and still maximize their electricity output.

Analysis of utilizing nuclear power without energy storage for all power requirements demonstrates the economic challenges of attempting to use nuclear plants for more than baseload demand.. For high capital cost plants such as nuclear reactors, the marginal cost of power climbs quickly when attempting to meet over $70 \%$ of demand due to reduced capacity factor. As shown in Figure 3, at 70\% demand, the incremental relative levelized cost of energy multiplier is just over 1 . At $90 \%$ demand, the incremental LCOE jumps to about 2.25 , and it exceeds 3.5 by $95 \%$. 


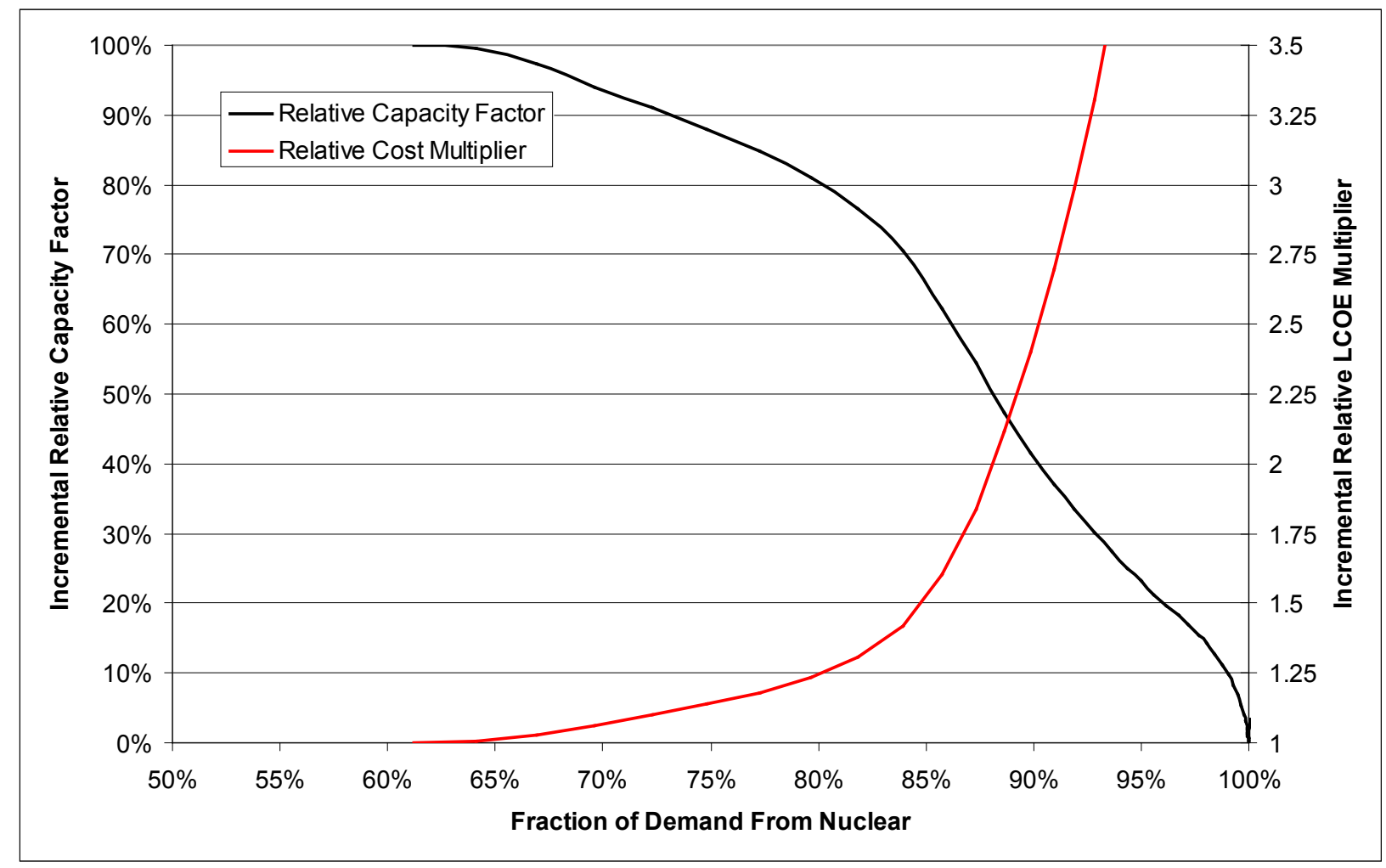

Figure 3. Incremental capacity factor and LCOE multiplier of nuclear achieving de-carbonized scenarios

Source: Denholm (2011)

Denholm examined the potential role of thermal energy storage as a solution to the economic challenges posed by variable resources and high marginal cost factors. Thermal storage helps overcome the uncertainty of incorporating variable resources by increasing ramping capability and reactor capacity factor. With storage, heat generation at baseload nuclear plants can operate at an economically desirable constant rate. Rather than varying the amount of power produced, power generators vary the amount of energy that goes directly into electricity and how much goes into storage according to demand. Additional power can be produced during times of high demand from stored energy.

Thermal storage is about $95 \%$ efficient over a 24 -hour period and has a lower cost than many of the other energy storage options. Hence it is a possible solution for balancing daily variations from thermal generation facilities like nuclear plants, coal power plants, and concentrated solar power plants. Over longer periods, thermal storage provides diminishing returns, so it is not currently applicable for balancing seasonal variations in resources and demand.

Denholm analyzed the effects of variable generation on the net load (load that needs to be met by additional generation including baseload) and presented a set of load duration curves with no variable generation, with $30 \%$, and with $50 \%$. He used the REFlex reduced form dispatch model to identify reactor and storage conditions and estimate capacity factors at various renewable energy penetrations and power block sizes (Denholm, 2007). 
Denholm concluded by demonstrating how the addition of thermal storage to nuclear plants boosted the nuclear fleet capacity factor across a range of high-renewable scenarios. Table 1 describes the scenarios and the resulting nuclear fleet capacity factor is shown in Figure 4.

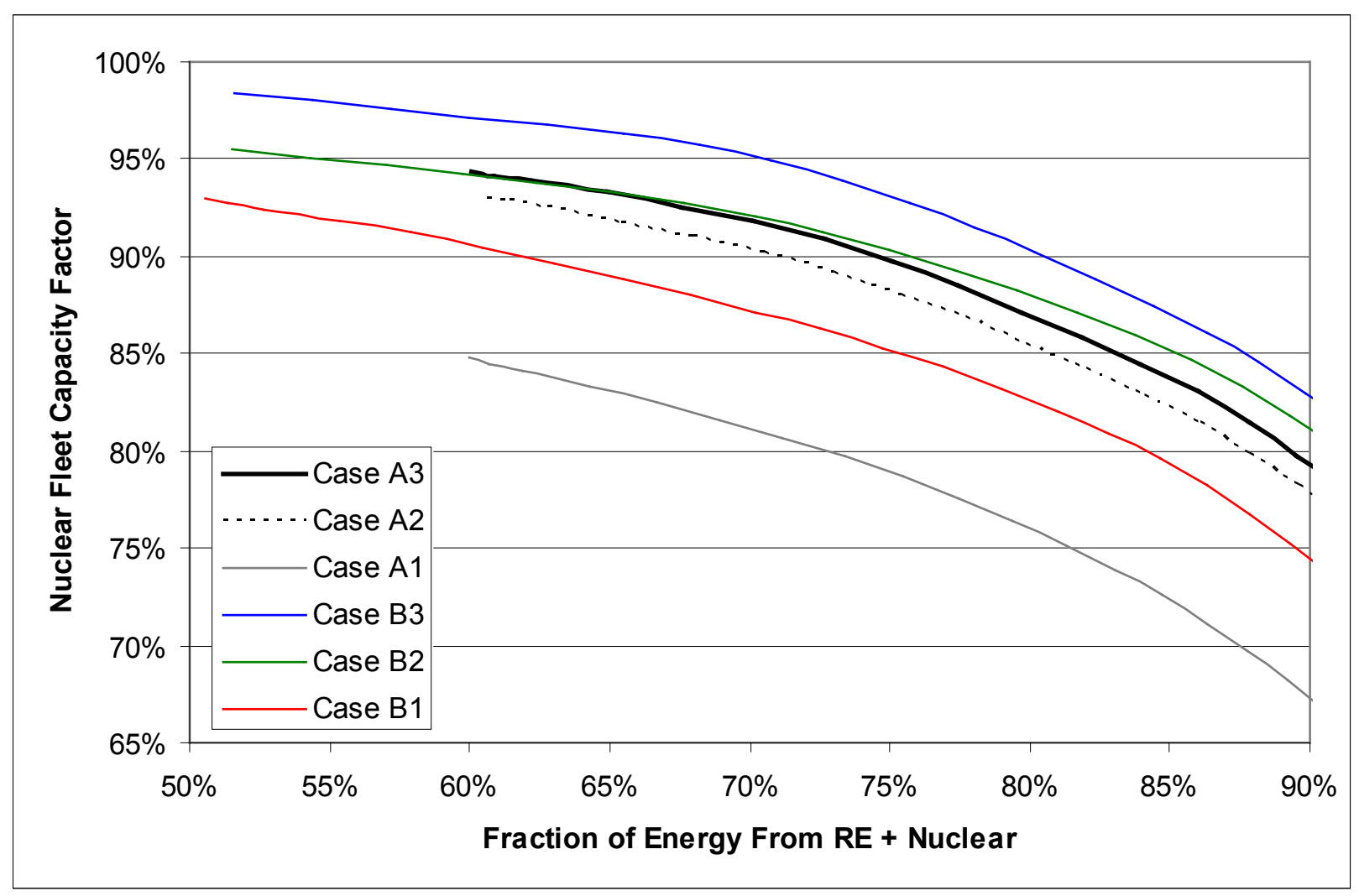

Figure 4. Nuclear fleet capacity factors in various high renewable penetration scenarios Source: Denholm (2011) 
Table 1. Scenario Descriptions

\begin{tabular}{|l|l|l|l|}
\hline Case Number & \multicolumn{1}{|c|}{$\begin{array}{c}\text { \% Energy From } \\
\text { Renewables }\end{array}$} & $\begin{array}{c}\text { Mix of Renewables } \\
\text { (Wind/PV/CSP) }\end{array}$ & $\begin{array}{c}\text { \% Nuclear Plants } \\
\text { w/Thermal Energy } \\
\text { Storage }\end{array}$ \\
\hline A1 & 60 & $60 \% / 25 \% / 15 \%$ & 0 \\
\hline A2 & 60 & $65 \% / 20 \% / 15 \%$ & $100 \%$ \\
\hline A3 & 60 & $60 \% / 25 \% / 15 \%$ & $100 \%$ \\
\hline B1 & 50 & $60 \% / 25 \% / 15 \%$ & 0 \\
\hline B2 & 50 & $60 \% / 25 \% / 15 \%$ & $50 \%$ \\
\hline B3 & 50 & $60 \% / 25 \% / 15 \%$ & $100 \%$ \\
\hline
\end{tabular}

\subsection{Southeast Defense Energy Initiative and the U.S. Energy Freedom Center ${ }^{\mathrm{TM}}$}

The Savannah River National Laboratory and a coalition of DOD, DOE, and U.S. industry are designing and deploying an ambitious regional energy surety project to guarantee energy supply to federal facilities in Georgia, the Carolinas, and Virginia. Dubbed the Southeast Defense Energy Initiative, the coalition aims to deploy working hybrid energy systems. In addition to serving as a real-world case study of hybrid energy systems, the Initiative also offers what Ben Cross from the U.S. Department of Energy, delivering a presentation on behalf of Mike Navetta, described as "an attractive business model" for such projects (Navetta 2011).

In the near term, the Initiative aims to create islanded micro-grids for regional military bases. These grids will be powered by an integrated portfolio of initially renewable resources and later with SMRs. Cross discussed the pros and cons of several SMR designs that component project teams are evaluating: B\&W mPower (125 MWe), NuScale Power Module (45 MWe), Westinghouse SMR ( 225 MWe), Hotec HI-SMUR (140 MWe), Hyperion Power Module (25 MWe), GE-Hitachi Prism (299 MWe), General Atomics EM2 (240 MWe).

Over the long term, the vision is to create true hybrid energy systems to foster industries that can encourage economic development in the region. Initiative designers also hope to address a common concern about nuclear power—radioactive waste — by recycling used nuclear fuel, depleted uranium, and plutonium as fuels rather than placing it in perpetual storage.

Because the United States imports hydrocarbon fuels rather than electricity, the Initiative established an energy security goal of creating viable synthetic and alternative fuel sources. The Initiative aims to economically synthesize transportation fuel from biomass using process heat and hydrogen from nuclear reactors. At the Savannah River Site (SRS), a biomass cogeneration plant came online in September 2011. The new bioplant, which is designed to generate 20 MWe and $200,000 \mathrm{lb} / \mathrm{hr}$ of steam, allows SRS to achieve its 2020 goal of $80 \%$ reduction in GHG 
emissions in 2011, nine years ahead of schedule. The project envisions 100\% GHG emissions reductions by 2030 .

The business model includes contributions from government and the private sector. DOD contributes host sites for SMRs and renewable projects and commitments to purchase energy through power purchase agreements, energy savings performance contracts, utility energy services contracts, and enhanced use leases. Private sector partners contribute third-party financing, energy surety assessments, engineering design, licensing and permitting, procurement, construction, commissioning, O\&M, and other services. While a long term regional vision is already in place, development is focused on incremental steps and beta projects. Power facilities and other projects are being commissioned for turn-key delivery. Table 2 lists value propositions for the different Initiative partners.

Table 2. Value Propositions for Partners in Southeast Defense Energy Initiative

\begin{tabular}{|c|c|c|c|}
\hline DOD Installations & $\begin{array}{l}\text { DOE/Savannah River } \\
\text { National Laboratory }\end{array}$ & SMR Vendor & Utility Partner(s) \\
\hline $\begin{array}{l}\text { 1. Satisfies executive } \\
\text { orders for carbon } \\
\text { footprint reduction } \\
\text { and increasing use } \\
\text { of renewable } \\
\text { 2. Increases energy } \\
\text { security by enabling } \\
\text { power islanding and } \\
\text { securing predictable } \\
\text { power costs }\end{array}$ & $\begin{array}{l}\text { 1. Provides major step } \\
\text { toward vision by } \\
\text { creating a source of } \\
\text { used fuel for } \\
\text { recycling R\&D } \\
\text { program } \\
\text { 2. Reduces carbon } \\
\text { footprint via } \\
\text { proposed power } \\
\text { purchase } \\
\text { agreement with } \mathrm{Ft} . \\
\text { Gordon }\end{array}$ & 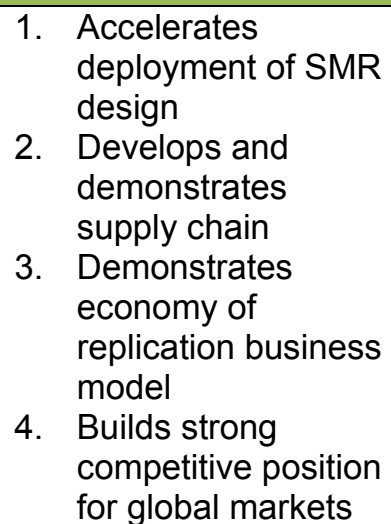 & 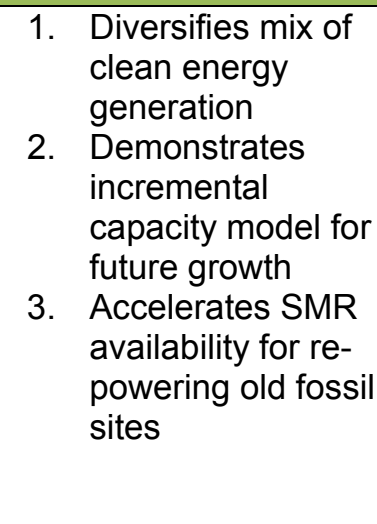 \\
\hline
\end{tabular}

The U.S. Energy Freedom Center represents the end-state vision of the Initiative that closes the nuclear and carbon fuels cycles. The Center is planned as an SMR development and demonstration complex that will utilize nuclear process heat to produce hydrocarbon, synthetic, and alternative fuels, and will spawn energy related manufacturing and other supply chain vendors in the surrounding region. Together, the Center and surrounding manufacturing facilities are intended to create sustainable manufacturing and energy production jobs in the "regional energy corridor."

\subsection{Small Reactors for Energy Supply: Islanded Generation and Load Management}

Philip O. Moor of High Bridge Associates, with the help of his colleague Bruce Alatary, introduced the advantages that SMRs provide for the challenges and threats of the modern power system. Moor stated that one of the challenges is that mismatches between generation and load cause frequency mismatches and require a variety of sources to generate and store power (Moor and Alatary 2011). 
Another challenge that Moor identified is managing disruptions. The current power system includes baseload generation, spinning reserve with rapid ramp up, and other fast-start units like simple gas turbines. Any disruption to this electricity supply chain can be costly and require long recovery times. These disruptions include natural threats like earthquakes and severe weather, as well as manmade threats such as vandalism, cyber attacks, and terrorism. Furthermore, existing energy storage options only provide short-term solutions for grid disruptions.

Moor defined the Smart Grid as a collective term for communication and control enhancements to the electricity grid using digital information and advanced controls technology. It dynamically optimizes grid operations and resources to get power where it is needed, when it is needed, while minimizing peaks and spinning reserve requirements. Moor identified the challenge of protection from increased susceptibility to cyber attack due to advanced computer technology.

Moor advocated for SMRs as an alternative, non-fossil fuel generation source to enhance system reliability. SMRs offer secure multi-year operation that can be run independent of the grid if desired. Like other nuclear options, SMR operations are free of greenhouse gas emissions. Like other nuclear power technologies, thermal energy from SMRs can be used for ancillary purposes like district heating and industrial process heat to enhance cycle efficiency. In addition, SMRs are compatible with renewable resources like wind, solar, biomass, and tidal power.

SMRs could also form the basis of a localized or "islanded" grid that is isolated from the larger power grid either geographically or by design. Moor described hypothetical micro-grids based on paired SMRs with backup diesel generators used to guarantee power to essential services. He stated that while water-cooled SMRs require automated systems, liquid-metal cooled and gascooled SMRs inherently follow load. Thus they have advantages in an islanded grid. When electricity demand is low, the SMR could provide energy to ancillary services like water purification, district heating, and hydrogen production.

Micro-grids are another option that Moor described. A secure micro grid is linked to the full grid but can act as an islanded grid to support mission-critical and support services. The intent is that it responds to the loss of the full grid instantaneously and remains intact. The control system of a micro-grid needs to be optimized for fast changes to the reactor, steam-turbine generator, and load (especially to reduce non-critical loads).

Moor suggested R\&D needs to ensure the viability of the concept in real-world situations:

- Security protocols to minimize risks from physical and cyber attack

- Smart grid protocols to integrate generation types and load variations, and protocols to foster innovation and incentivize equipment developers to market a range of robust equipment

- Design simulations developed with multiple nodes in the actual generation -load scenarios

- Stability analysis program to coordinate load/generation on micro grids, including SMR-based grids 
- Transient analysis to determine spinning reserve requirement to safely and efficiently operate the micro grid.

\subsection{Grid Scale Hybrid Energy System: Integrating Renewable and Nuclear Power}

Richard D. Boardman of Idaho National Laboratory (INL) showcased nuclear / renewable / fossil hybrid energy systems research that indicates nuclear hybrid integration options can be economically advantageous even without implicit or direct penalties for $\mathrm{CO} 2$ emissions and before foreign fuel import cost premiums are taken into account. Nuclear/renewable/chemical plant hybrids, such as the one diagrammed in Figure, can help stabilize the grid and allow greater penetration of both clean renewable and nuclear energy into the market. The benefits are achieved with:

- Full utilization of capital investments

- Reduced requirements for electrical power storage and/or fossil fuel peak power generation units

- Coordinated production of cleaner transportation fuels, including synfuels produced from renewable biomass and indigenous natural gas and coal (thus extending the life of fossil fuels and reducing their carbon footprint on the environment).

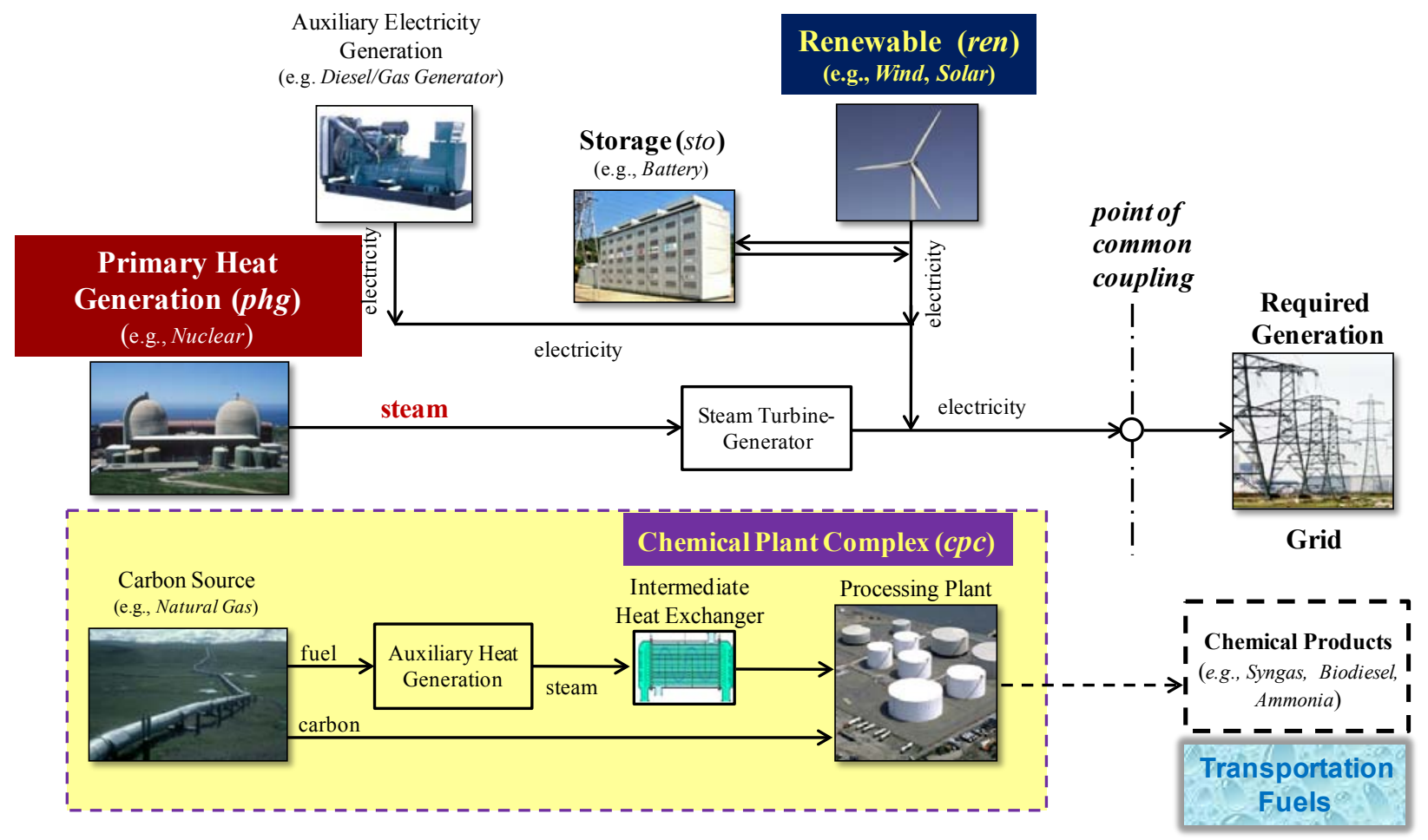

Figure 5. SMR/natural gas/renewable power hybrid system

Source: Aumeier et al. (2011)

The INL analysis shows hybrid systems can significantly increase U.S. production of biofuels and lead to a sustainable energy infrastructure. INL has developed detailed process models and economic models to evaluate the technical and economic value of using nuclear energy beyond 
electrical power production. The integration of nuclear energy with conventional and future fossil fuels plants that produce hydrogen, ammonia, or transportation fuels have been shown to offer many advantages. These benefits can also be realized when hybrid systems are integrated with the electrical grid to synchronize clean nuclear power generation with variable grid demand and intermittent renewable power generation.

INL is now developing dynamic computational models to investigate the sensitivity of "achievable load-following power generation" for nuclear / renewable / chemical plant hybrid systems. Such systems can prevent investments in expensive power generation assets that are required to compensate for intermittent renewable power generation. Preliminary simulations show that power storage systems such as electrical-chemical batteries can reduce, but will not eliminate, the need to back up a significant part of diurnal power and peak power demand with spinning reserve.

By actively managing the output of hybrid energy systems that produce power, steam, chemicals, or fuels, the systems might effectively reduce the need for power storage or additional peak capacity and capital requirements for each. Excess steam and electricity can be used to produce hydrogen, syngas, and chemicals that can be readily converted into transportation fuels. In this manner, all of the assets are operated near their name-plate capacity. Adding multi-purpose nuclear power to the mix reduces the total capital investment required to balance the grid and to produce transportation fuels. It can reduce the risk of supply and cost volatility of fossil fuels.

Normalized capital and operating costs and revenue comparisons among wind and natural gas peak power generation, coordinated traditional nuclear and wind generation, and integrated nuclear / renewable / chemical plants indicate that financial returns can be increased when renewable power generation exceeds about $20 \%$ of the annual electrical power demand. Any of the emerging small modular nuclear reactors can be used, and size, number of modules, and temperature output can be adjusted to meet system design requirements. The hybrid systems can be deployed at any location, so long as they are coupled with the grid.

Boardman described nuclear energy as an energy solution "enabler," not just a heat machine. However, for integrated, highly coupled hybrid energy systems, it is important to:

- Investigate challenges related to greater penetration of renewable energy and the effects that the dynamic characteristics and potential synergies among hybrid system components may have in the overall stability of grid operations

- Suggest and evaluate hybrid energy system options in order to address identified challenges

- Compare, in a dynamic setting, traditional and advanced hybrid energy systems

- Conduct dynamic cost analyses, including addressing costs of variability, in order to investigate economic viability of hybrid systems.

\subsection{Non-Technical Considerations for Small Modular Reactors}

Do SMRs offer a practical alternative to the conventional power system? Phillip Bond of White Sands Missile Range provided some contrarian opinion on the practicality of SMRs for military facilities. Speaking from a personal perspective and not officially on behalf of the U.S. 
Department of Defense or White Sands Missile Range, Bond described a series of budget rules, mandates, and other factors, which pose barriers to implementation (Bond 2011).

Primary among implementation barriers are the rules of the federal budget process. Operation and maintenance funds (O\&M) are appropriated annually and cover base operations, including power and fuel. O\&M funds are normally available for obligation for one fiscal year with no carryover (Defense Acquisition University 2009). Congress appropriates O\&M funding as part of the total DoD budget. Thus, in essence, O\&M funding competes with acquisition (investments in new equipment and procurement of total systems) and personnel (salary and certain services) for a share of the total DoD budget. The current constraints make large-scale investments with long-term return on investment such as SMRs, very problematic.

At the same time, the military must meet other targets for energy and environmental performance, including reducing overall energy use, reducing water use, increasing consumption of renewable energy, and reducing GHG emissions. In general, the DoD is reducing its total energy consumption and meeting its goals around water use. The EIA shows a fairly rapid reduction in energy consumption by the U.S. government since 1975 (Figure 6). The nearly 400 Trillion BTU reduction from 1975 to 2009 represents a roughly 69 million barrels of oil per year reduction.

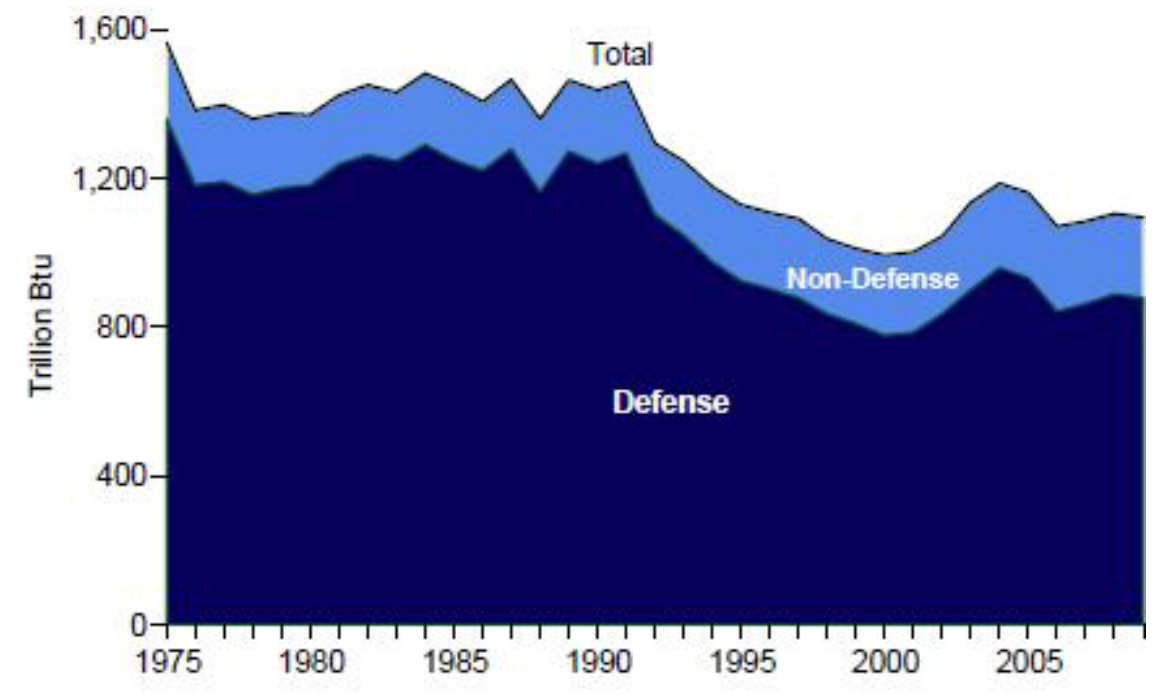

Figure 6. U.S. government energy consumption by agency (1975-2009)

Source: Energy Information Administration (2009)

Within the military's share of energy consumption, electricity represents only about $12 \%$. Jet fuel is $52 \%$ and other fuel needs total around 25\%. (Deputy Under Secretary of Defense Installations and Environment 2007).

Against this customer needs assessment, SMRs in isolation provide a solution (electricity) for a need that Bond does not believe DOD has. In addition to being a relatively small portion of the DoD energy appetite, many DoD installations have relatively modest electrical demands when compared to SMR capability, are geographically relatively isolated, and are often in locations with limited water availability. All of these could reasonably be expected to increase the cost of 
electricity generation via SMR. Conversely, the DoD has a very high demand for liquid fuels and the national demand for liquid fuels to support the transportation sector is only expected to intensify. Hybrid energy systems as proposed and discussed elsewhere in the workshop could address the liquid fuels need, but the effort should clearly be targeted towards using SMRs to domestically generate liquid fuels at a price that is comparable to conventional fuels. Regardless, under current constraints, the military should be viewed as an end customer rather than an investor.

\subsection{Small Modular Reactors-NRC Readiness for Licensing Reviews}

Before the Three Mile Island reactor incident, the average time from construction permit to full operation of a new U.S. nuclear facility was 5 years. Since Three Mile Island, that time has averaged 11.5 years. With nuclear power seen as an essential part of the U.S. power mix, and with a new generation of nuclear reactors coming online, David Matthews from the U.S. Nuclear Regulatory Commission (NRC) provided an update on his agency's readiness for licensing SMRs. NRC has been working to streamline the overall review process by reviewing "combined" license (COL) applications that would authorize both construction AND operation of new reactors, if the COL was ultimately issued.

Matthews also highlighted differences in the review and approval process for the category of "advanced" reactors, which includes SMRs. At present, NRC reviews of large light water reactors (LWRs) take on the order of 3-4 years. That time period is for the first of kind reactors, which would describe all of the SMRs. At the conclusion of the design review, NRC issues a rule in the federal register related to that design. Future applicants for a combined license can potentially accelerate the review process for duplications of an approved design by citing the federal rule as precedent.

During the reviews of SMRs, the NRC will need to take a distinct approach on several issues. Some of these issues include:

- Control Room Staffing - NRC is working to determine the appropriate number of operators per module when applied to multi-module or small reactors. 10 CFR $50.54(\mathrm{~m})$ has prescriptive requirements.

- Risk-Informed Licensing - NRC is developing licensing processes to incorporate risk-informed, performance-based approaches into reviews and guidance for integral pressurized water reactors. Longer term, the agency plans to develop similar processes for next generation nuclear plants.

- Emergency Planning - NRC is addressing EP requirements for SMRs with passive design features, smaller source terms, and longer transient response times.

- Mechanistic Source Term - NRC previously deliberated on use of design-specific, event-specific source terms. Now the commission is modernizing the accident consequence source term using a mechanistic approach commensurate with the inherent safety of advanced reactor designs.

- Physical Security - NRC is answering questions related to physical security of SMRs. Do SMRs' small size, passive features, and other unique physical design 
characteristics affect plant security design? Can the number of security staff be reduced? Can the size of the protected area be reduced?

In addition, NRC is examining unique issues related to manufacturing licenses, facilities licensing, operator fees, insurance, and funding for decommissioning. 


\section{Workshop Proceedings, Part 2: Identifying Synergies}

Following introductory presentations and discussion, workshop participants began a series of facilitated discussions designed to identify and prioritize nuclear/renewable synergies.

Participants assigned priority according to perceived highest impact, which was defined as a balance between scale of the issues or opportunities, probability of success, near-term potential, complexity, cost, and ability to move to implementation.

This portion of the workshop started by soliciting questions inspired by the presentations and discussion. In no particular order, those questions included:

- What is the cost?

- Will the public be more supportive of hybrid nuclear energy systems than nuclear alone?

- What thermal storage or battery storage is needed with hybrid energy systems?

- Do SMRs have flexibility to broaden the market for nuclear energy?

- What are the functional requirements for energy systems (security, cost, clean air, etc.)? These are necessary in order to optimize the system.

- Can we make a case for nuclear/renewable energy for DOD?

- What issue is at the heart of what we are trying to solve?

- Can synergies reduce nuclear stigma?

- What are the near-term and long-term objectives?

- What role can or should crosscutting technologies play?

- What additional data do we need to begin analysis?

- Who or what organizations can lead the development of a cohesive approach to hybrid energy systems?

- How can we optimize domestic energy production?

- What nuclear technologies best support load following? Can they be better?

- How can we encourage a "team" effort in this field?

- In a hybrid system, how will we license the reactor?

- How do we make price at the pump as predictable as price at the plug?

- How do we better understand synergies between nuclear energy and other heat sources like concentrated solar?

- Is grid stabilization the key missing ingredient?

- How can we influence procurement rules to allow SMRs or hybrid innovations?

- What are the highest value R\&D targets?

- How do you encourage greater cooperation between nuclear and renewable?

- How can the total energy system (electricity, fuels, heating/cooling) be optimized?

- How do we balance economic, environmental, and security issues in energy?

- How do we accommodate diverse energy characteristics and needs within feasible/economical infrastructure?

- As a group, what's our mission statement? What need are we trying to fulfill?

- How do we get the market to embrace a radical change?

- What insights are needed to inform others of the value of hybrid systems?

- Are there geospatial issues?

- How would DOE engage in a programmatic cross-disciplinary approach? 
- What are the enabling R\&D needs for SMRs and hybrid systems?

- Who or what is the ultimate driver?

- Do we understand the heat-to-chemical process?

Next, the group assembled a set of nine broad categories of synergies and selected three priority categories for further brainstorming and discussion. The complete list of synergy categories is provided below, with the selected priorities highlighted in bold text. Sections 3.1-3.3 describe the results of the discussion in each of the three priority categories: business model development, energy for transportation, and hybrid energy systems.

- Balancing capacity on the grid - Nuclear energy provides base load. If it can be ramped sufficiently or energy storage can be used, it can smooth the load provided by variable resources. Can storage technology be advanced to economically provide the remaining balance in a grid supplied by both nuclear and renewables?

- Business model development - The theoretical case for hybrid energy systems is strong, but current market and regulatory environments favor investment in and maintenance of the status quo. What are obstacles to market acceptance? What is necessary for a practical business model?

- Energy for industrial applications - Many industries require high amounts of heat and/or hydrogen. Can hybrid energy systems produce energy to supply such industries? Are efficiencies gained by doing so? And would industry need to be able to grow around the energy source, or can the energy source be built near industry?

- Energy for transportation - Many types of vehicles (airplanes, jets, tanks, etc.) will require liquid fuels in the foreseeable future. Currently, those fuels are primarily derived from petroleum with hydrogen added during the refining process. Are there combinations of nuclear and renewable energies that can provide potential domestic production of transportation fuels?

- Hybrid energy systems - Thoughtfully designed hybrid nuclear / renewable energy systems could form the basis of a sound national energy policy. Hybrid systems improve sustainability and energy security without reducing quality of life. What possible hybrid systems warrant further investigation?

- Islandable micro-grids and SMRs - The interconnected grid helps provide power across a wide area, but disruptions in that grid cause corresponding wide interruptions of power. Do independent small grids with both SMRs and renewable generation offer an appropriate alternative?

- Lessons learned - While deployment of hybrid systems is a new process, design and deployment of the component parts are not. Can past experience illuminate future possibilities? Are there lessons from the nuclear experience that will help renewables as they grow?

- Permitting, licensing and financing - Assuming all engineering issues of hybrid systems can be resolved, these systems could still face practical challenges to implementation. Because hybrid systems are new, they defy standard categorization for ownership as well as for review and approval processes. In addition, risk and 
financial models need to be developed to address the combinations of components. What can be done to address these real-world challenges?

- Policy and institutional opportunities - Hybrid energy systems incorporate multiple technologies and outputs. Thoughtful creation of such systems can also incorporate regional planning and economic development. What challenges and opportunities do these power systems pose to current legislative and institutional structures?

An additional category - common R\&D needs - was considered, but dropped from the list because it was also a subset of each of the other categories. R\&D encompasses research and development of technologies, materials, and processes that could be applied to both nuclear and renewable energy options. Examples include high-temperature materials that could be used in either nuclear reactors or heliostats; thermo-chemical water splitting options; and systems, such as batteries, for energy storage.

\subsection{Nuclear/RE Synergy: Energy for Transportation}

The breakout group discussed the potential for domestic transportation fuels with a primary, but not exclusive, focus on nuclear-generated hydrogen and heat that might be utilized for biofuel production. The biofuels focus was based on the fact that many types of vehicles (airplanes, jets, and tanks, among others) will require liquid fuels in the foreseeable future and biomass is an excellent, domestic source for carbon in those fuels. Other carbon sources that were discussed include atmospheric carbon dioxide, coal, and natural gas.

One of the issues with the current options for converting biomass to liquid fuels is that the production processes consume a large percentage of the feedstock's energy to generate the heat, hydrogen, and/or electricity necessary within the production process. Channeling heat produced by nuclear reactions and electricity and/or hydrogen from the nuclear plants eliminates that problem and could allow for more efficient and economical conversion into liquid transportation fuels. The group estimated that the fuel yield from biomass could be nearly tripled if the heat, hydrogen, and power necessary for processing came from an external source.

Because the system is "agnostic" about the source of carbon, it can be also adapted to utilize regional carbon sources and thus support regional employment (loggers, coal miners, farmers, and others).

Even though the group focused on liquid biofuels, it recognized that low cost hydrogen is the key and that the marketplace should determine its best use. Other potential uses for hydrogen in the transportation sector include direct use of hydrogen in FCEVs, use of hydrogen for oil refining, and use of hydrogen in producing Fischer-Tropsch liquids from coal. The group also recognized that if the hydrogen is produced via water-splitting, a large amount of high-concentration oxygen would be available. That oxygen could be used for oxy-combustion or other opportunities to increase efficiency in power-generation and industrial sectors.

Why is this option important? A nuclear-based production process might improve cost competiveness of biofuels and transform their potential from boutique fuels to viable alternatives to oil. Converting to a biofuels-based transportations system would contribute to several national policy goals: reducing dependence on oil; reducing GHG emissions; improving balance of trade by reducing oil imports; and enhancing economic and national security. 
The theoretical possibility of producing large amounts of additional hydrogen from nuclear processes is not without challenges, however. Challenges include:

- Establishing a political and organizational support structure for the development of hybrid energy systems within the Department of Energy or elsewhere in the federal government

- Realizing sufficient political support for oil reduction and GHG reductions

- Developing economic options for combining heat/power/hydrogen from nuclear facilities for generating fuels

- Developing business cases and opportunities where investments will be made. Projects considered require large capital investments and cross business sectors; thus they are likely to require partnerships

- Overcoming the benefits of sunken capital in the existing fuel infrastructure

- Developing technologies to increase the density of biomass for transportation; 40 lbs./cubic foot allows economical long distance transport, which in turn permits larger biorefineries that have energy demands more similar to the production of nuclear facilities

- Addressing concerns about nuclear safety in order to increase political and public support for such a system.

To address these challenges and other hurdles for implementation, the workshop team identified and prioritized opportunities for analysis and $R \& D$.

Priority areas for analysis were:

- Top-level systems analysis that includes what ifs, econometrics, customer inputs

- Cost analyses for scenarios

- Scale balancing and optimization.

Other potential areas for analysis included interagency cooperation/jurisdictional issues; crop densification; conversion processes for biofuels; safety and security issues related to collocating nuclear and chemical facilities; agricultural impacts; transportation systems including high-speed train lines; spatial aspects of a biomass fuel system and distributed production; transportation logistics including fuel specifications; and developing process flowsheets for fuel production scenarios.

Priority areas for R\&D were development of:

- Processes where all of the biomass is converted to biofuel instead of a large portion used for heat, electricity, and hydrogen

- Processes that provide low cost hydrogen with a focus on nuclear processes

- Energy crops with high energy-to-land densities. 
Other identified R\&D opportunities included biomass densification, improving reliability and durability of materials for containment of high temperature heat sources, demonstration of a large-scale hydrogen vehicle fleet, and optimizing nuclear reactors for heat production.

\subsection{Nuclear/RE Synergy: Hybrid Energy Systems}

This breakout group built on group discussion about the potential for hybrid energy systems. To frame the discussion, the group started by defining hybrid energy systems as those with multiple inputs, such as nuclear and renewable, and multiple outputs: electricity, fuels, chemicals, and possibly others. The attraction of this topic rested in the idea of a system, a highly coupled set of sources, services and storage customized to meet regional needs and optimized for market practicality. For this group, such a system offered the potential for meeting the World Commission on Environment and Development (1987) definition of sustainable solutions that framed the workshop and particularly for integrating SMRs and renewables.

Initial discussion focused on the potential, both social and technical. The group believed that thoughtfully designed and carefully integrated hybrid energy systems could form the basis of a sound national energy policy, in part because hybrid nuclear/renewable systems improve sustainability and energy security without reducing quality of life. Hybrid systems also increase domestic energy production, which improves energy security and balance of trade ratios.

From an environmental perspective, hybrid nuclear/renewable systems also offer unique advantages that are the result of, in part, a "blank page" approach to energy system design. Hybrid systems could provide better utilization of resources and synergies that would make the system more financially attractive than its component parts. Plus, hybrid systems need not be one size fits all. Instead, they can facilitate a distributed framework where the components, particularly the renewable components, can be customized to match regional supplies such as natural gas, solar, wind, or biomass.

In practice, such systems face several practical institutional/jurisdictional, technical, and political hurdles to implementation. Regulatory agencies for nuclear and renewable energies are separate, and combinations of the two are untested waters. Stovepipe issues extend beyond the regulatory framework, too. Because they defy easy categorization and thus ownership by single entities, hybrid systems would likely have difficulties with financing and risk assessment and management.

Considering these challenges, the group felt that one of the primary enablers has to be leadership with a common desire to find solutions, strong roles and responsibilities, and the ability to overcome jurisdictional obstacles. Appropriate roles for government, industry, and national laboratories need to be defined and perspectives from all energy system stakeholders, from vendors to chemical plant operators, need to be incorporated.

Other challenges are of a more technical nature. Hybrid systems are forging new ground in terms of operational integration, and appropriate interface technologies may not yet exist. Politically, nuclear power in any form typically faces strong opposition. Together, these hurdles create another one: cost. Working through the legal, technical, and political issues will require undetermined time and expense which, at least for the trail blazer, could place hybrid systems beyond the point of economic feasibility. 
In order to move ahead toward the promise of hybrid energy systems, the group identified and prioritized several areas for analysis and research and development.

Priority topics for analysis were:

- Requirements definition - The task group saw the importance of identifying system needs and resources, defining the overall objectives, and identifying tradeoffs between them.

- System design - Because the possibilities for hybrid systems are so many, the task group saw a need to define what types of systems best fit market needs and available resources.

- Engineering components - The task group saw a need to examine the effects of different generation services, intermediate carriers, storage systems, and tradeoffs with storage/service options.

Other identified topics for analysis included benchmarks or standards to create shared language for research and discussion; market implications; best geographical locations for hybrid systems; success metrics; support for business case development; challenges of integrating different energy sources; probable or ideal first steps to implementation; and relative priority of primary services (electricity) and secondary services (chemicals, for example).

The group identified the need for multidisciplinary teams with key labs working together in all R\&D performed. Priority areas for R\&D were:

- Integrated, dynamic models

- Pilot integration especially with disparate technologies

- Enabling technologies such as energy storage, reactor design, energy conversion components, and interface components.

The team felt that some R\&D, particularly that involving enabling technologies, should be done through pilot projects. Other identified topics for R\&D included market design, economic modeling, and the overall range of options for hybrid energy systems.

\subsection{Nuclear/RE Synergy: Business Model Development}

The third breakout group discussed business model development and scenarios under which nuclear and renewable energy synergies could be realized. Based on personal knowledge and presentations on the previous day, the participants agreed very quickly that a wide-ranging integration of nuclear and renewable technologies was possible. The group decided early in the proceedings that it would not be fruitful to try to enumerate and describe the many business models that may be possible because there are so many questions and so many possibilities. Instead the group focused on identifying common issues that everyone developing specific plans for nuclear/renewable business models will need to address.

All business plans will require a vision; identification of potential benefits and barriers; and a combination of policy, players, and funding mechanisms. The group identified the need for 
leadership to bring together a wide range of players and develop an environment where businesses will invest. Business plans will also need to answer the following questions:

- Who will share risk to get us from where we are now to where we are going in 20 years?

- What role shall government play?

- What should be the roles of the public utility commissions?

- What will the markets look like?

The group saw expansive markets and huge potential while thinking about synergies between nuclear and renewable energy. However, it was recognized that in order for this to become a reality, a bold vision and strong leadership is absolutely essential. The leadership must involve multiple stakeholder points of view to tap and a wide range of players. Various stakeholder viewpoints can be seen as useful input rather than a set of constraints as is often the case. Public/ private partnerships have the potential to provide this vision and leadership.

The group was concerned that we currently have an unsustainable energy model whose continuation is risky, so they recommended developing a new picture. A plethora of reasons were discussed, indicative of the compelling case that could be made for pursuing a synergistic strategy.

These drivers fell into two classes: first, the national significance of these synergies and, second, their timeliness (how and why near-term action is necessary).

Drivers identified in the first class relative to national significance were economic and national security, safety, sustainability, and scalability and local independence.

The U.S. economy and the U.S. energy supply go hand in hand. Protecting national security and the U.S. economy requires a safe, dependable, plentiful, and inexpensive supply of electricity and transportation fuel. Strategically located SMRs could be an important component of the national grid safety issue. The group recognized that any such system must be available to all Americans, in remote areas as well as in the largest cities. Furthermore, this supply must be something that can be used for years to come, without compromising the ability of future generations to meet these same needs. Having some amount of energy that is independent of large localized production is important; local support for energy protects security - the value added for localized grid and distribution is safety and independence.

Drivers identified in the second class (how and why near-term action is necessary) were sharing risk, the importance of "dividing and conquering" early on, and the advantage of having a vision and roadmap that define the problem being solved and a path toward the solution.

The group identified the following challenges to achieving these synergies and developing potential business models:

- Technical difficulty in integrating nuclear and renewables, especially with regard to integration of base load and intermittent supply and grid management 
- Engaging all stakeholders and reconciling disparate stakeholder values. A crucial issue here is whether government or industry should lead; government can lead through policy and RD\&D funding which helps to determine what industry can do; industry leads through capital investment decisions

- High risk

- Quantification of values and risk

- Establishment of end goals.

Other questions were raised relating to this topic area:

- What if grid reliability became less important?

- Could wind/solar cooperation be mooted with grid management if larger regions were managed?

- What are the markets and how are we getting to the market?

A great deal of analysis and R\&D are needed in order to enable the synergy of nuclear and renewable energy.

The top analysis needs identified by the group were:

- Techno-economic and policy analyses

- Quantification of the risks of the current energy system

- Identification of the barriers to entry with the increasing complexity of integrated systems

- Gap analyses looking at the build-out from current to the future state

- Alternative model development and comparative analyses and trade studies to determine best possible end state(s)

- Grid management studies

- Products distribution studies

- Quantification of abstract benefits-economics studies

- Market acceptance studies.

The group also recognized that it is important to identify and include stakeholders who may not have been involved in developing previous energy plans - end users, state and federal policy bodies, industrial energy users, broad stakeholders - and to look at broad technologies as well as broad stakeholders. Leadership is critical. Various stakeholders have different perspectives on value than the general population.

The group did not specify R\&D topics to pursue. 


\section{Conclusions}

JISEA convened the Nuclear and Renewable Energies Synergies Workshop to foster discussion on new responses to U.S. energy challenges, especially reducing GHG emissions and dependence on oil, a majority of which is imported and which potentially is reaching a peak. In particular, the workshop was designed to determine if synergies in utilizing nuclear and renewable energy together could lead to potentially better responses to those two challenges.

The workshop participants concluded that yes, there are synergies between nuclear and renewable energy that could foster solutions to energy challenges and warrant additional investigation. Furthermore, the workshop attendees were motivated to study the synergies and develop potential implementation schemes for the ones that make the most sense. The participants' energy and motivation should be engaged to discover and analyze potential synergies.

The workshop participants identified nine broad categories of synergies: balancing capacity on the grid; islandable micro-grids and SMRs; energy for transportation; energy for industrial applications; hybrid energy systems; lessons learned; permitting, licensing, and financing; business model development; and policy and institutional opportunities. They prioritized two technical categories (energy for transportation and hybrid energy systems) and one institutional category (business model development) as having the greatest potential for impact. Further discussions were held on each of the three priority categories.

The group that discussed energy for transportation focused on production of liquid biofuels utilizing nuclear-generated hydrogen and heat. They recognized that other transportation opportunities exist but focused on liquid biofuels because the carbon source (biomass) is renewable and liquid fuels are likely to be needed for airplanes, jets, tanks, and many other vehicles in the foreseeable future. That group identified three priority analysis areas:

development of top-level system models, performance of cost analysis for various scenarios, and optimization of scales. They also identified three R\&D priority areas: developing biofuel processes that use all the biomass for the fuel (instead of utilizing some for heat), developing nuclear processes that generate low-cost hydrogen, and improving the energy-to-acreage density and cost of energy crops.

The group that discussed hybrid energy systems defined those systems as having multiple energy inputs (nuclear and renewables) and multiple products (electricity, fuels, chemicals, and possibly others). The advantage of considering hybrid systems is that a "blank page" approach to energy system design can be utilized and the opportunity can be optimized for each specific scenario. Using a "blank page" approach leads to better utilization of resources and synergies and, hence, a more financially attractive solution. The group identified strong leadership and integrated multidisciplinary teams from key labs as primary requirements to implement hybrid energy systems. They also identified three analysis priorities: requirements definition, analysis of system design options, and selection of engineering components. They identified three R\&D priorities: development of integrated, dynamic models; pilot-scale integration; and R\&D on enabling technologies such as energy storage, reactor design, and system components. 
The group that discussed business cases decided that it would not be fruitful to enumerate and describe the many potential business models. Instead they focused on common issues and drivers that everyone developing specific business models for these types of systems must address. The drivers fell into two classes: first, the national importance of these synergies (societal motivation); and, second, their timeliness (how and why near-term action is necessary). The group identified several societal motivations, including: economic and national security, safety, sustainability, and scalability and local independence. The second class of drivers (how and why near-term action is necessary) included: sharing risk, importance of "dividing and conquering" early on, advantages of having a vision and roadmap that define the problem being solved and offer a path toward the solution. The group also identified the following challenges for developing potential business models: technical difficulty in integrating nuclear and renewables, getting full stakeholder involvement especially with stakeholders whose values conflict, high risk, quantification of values and risk, and establishment of end goals. 


\section{References}

Appenzeller, T. (June 2004). "End of Cheap Oil." National Geographic Magazine. http://ngm.nationalgeographic.com/ngm/0406/feature5/fulltext.html. Accessed September 2011.

Aumeier, S.; Baldwin, T.; Boardman, R.; Cherry, R.; Garcia, H.; Grauer, D. (September 2011). "Grid Scale Hybrid Energy System: Integrating Nuclear and Renewable Power Generation with Fuels Production." Presented at the 2011 NREL Strategic Planning and JISEA Nuclear and Renewable Energy Synergies Workshop.

Bond, P. (September 2011). "Non-Technical Considerations for SMRs." Presented at the 2011 NREL Strategic Planning and JISEA Nuclear and Renewable Energy Synergies Workshop.

Defense Acquisition University (2009). Operations \& Maintenance Funds. Accessed at https://acc.dau.mil/CommunityBrowser.aspx?id=28980.

Denholm, P. (September 2011). "Flexible Nuclear Power for High Renewable Grids: The Potential Role of Thermal Energy Storage." Presented at the 2011 NREL Strategic Planning and JISEA Nuclear and Renewable Energy Synergies Workshop.

Denholm, P.; Margolis, R. (May 2007). "Evaluating the Limits of Solar Photovoltaics (PV) in Electric Power Systems Utilizing Energy Storage and Other Enabling Technologies." Energy Policy Vol 35, Iss 9, pp 4424-4433.

Deputy Under-Secretary of Defense Installations and Environment (2007). "Department of Defense Energy Use, Strategies and Goals." Presented at GovEnergy 2007. http://www.govenergy.com/2007/pdfs/procurement/Hancock_Procurement track_S3.pdf.

Energy Information Administration (2009). Annual Energy Review 2009. DOE/EIA-0384(2009). Accessed at http://www.eia.gov/emeu/aer/pdf/pages/sec1_24.pdf.

Energy Information Administration (September 2011). Petroleum Supply Monthly. http://www.eia.doe.gov/oil_gas/petroleum/data_publications/petroleum_supply_monthly/psm.ht ml. Accessed September 2011.

Forsberg, C. (September 2011). "Nuclear Energy for Variable Electricity and Liquid Fuels Production: Integrating Nuclear with Renewables, Fossil Fuels, and Biomass for a Low-Carbon World." MIT-NES-TR-015. Cambridge, MA: Center for Advanced Nuclear Energy Systems, Massachusetts Institute of Technology, $43 \mathrm{pp}$.

Forsberg, C. (September 2011b). "Nuclear Wind Hydrogen Systems for Variable Electricity and $\mathrm{H}_{2}$ Production." Presented at the 2011 NREL Strategic Planning and JISEA Nuclear and Renewable Energy Synergies Workshop.

International Energy Agency (2010). Key World Energy Statistics 2010. Pp. 6-7. Paris: IEA. 
"International Energy Statistics." (2011).

http://www.eia.gov/cfapps/ipdbproject/iedindex3.cfm?tid=2\&pid=27\&aid=12\&cid=US,\&syid=1 980\&eyid=2009\&unit=BKWH. Published by U.S. Energy Information Administration.

Lochbaum, D. (October 2007). “Got Water?” Union of Concerned Scientists.

http://www.ucsusa.org/nuclear_power/nuclear_power technology/got-water-nuclear-power.html.

Lyons, P. (September 2011). "U.S. Nuclear Power Policy and R\&D Programs." Presented at the 2011 NREL Strategic Planning and JISEA Nuclear and Renewable Energy Synergies Workshop.

Matthews, D. (September 2011). "Small Modular Reactors (SMRs): NRC Readiness for Licensing." Presented at the 2011 NREL Strategic Planning and JISEA Nuclear and Renewable Energy Synergies Workshop.

Moor, P., Alatary, B. (September 2011). "Small Reactors for Energy Supply: Islanded Generation and Load Management." Presented at the 2011 NREL Strategic Planning and JISEA Nuclear and Renewable Energy Synergies Workshop.

Navetta, M. (September 2011). "Southeast Defense Energy Initiative \& U.S. Energy Freedom Center ${ }^{\mathrm{TM}}$." Presented at the 2011 NREL Strategic Planning and JISEA Nuclear and Renewable Energy Synergies Workshop.

"Nuclear power plants in Europe." (August 2011). http://www.euronuclear.org/info/encyclopedia/n/nuclear-power-plant-europe.htm. Published by European Nuclear Society.

Our Common Future: Report of the World Commission on Environment and Development (1987). Accessed at http://www.un-documents.net/wced-ocf.htm in September 2011.

"Renewable Energy Consumption and Electricity Preliminary Statistics 2010." (June 2011). United States Energy Information Administration.

http://www.eia.gov/renewable/annual/preliminary/. Accessed September 2011.

Scheer, R.; Moss, D. (April 2011). "Post-Fukushima Reaction: Can Japan Shut Down Its Nuclear Power Plants?" Scientific American. http://www.scientificamerican.com/article.cfm?id=canjapan-do-without-nuclear-energy. Accessed September 2011.

U.S. Department of Energy, Office of Energy Efficiency and Renewable Energy (2009). Renewable Energy Data Book. DOE/GO-102009-2827. Golden, CO: National Renewable Energy Laboratory.

U.S. Energy Information Administration (April 2011). 2011 Annual Energy Outlook. DOE-EIA 0383(2011). Accessed at http://www.eia.gov/forecasts/aeo/pdf/0383(2011).pdf.

U.S. Government Accountability Office (2011). Commercial Nuclear Waste Effects of a Termination of the Yucca Mountain Repository Program and Lessons Learned. GAO-11-229. 
World Nuclear Association (2011). Report on Nuclear Power in Germany. http://worldnuclear.org/info/inf43.html. Access October 2011. 


\section{Appendix A: Workshop Participants}

The following people, alphabetized by organization name, participated in the JISEA-sponsored workshop.

\begin{tabular}{|l|l|}
\hline \multicolumn{1}{|c|}{ Name } & \multicolumn{1}{c|}{ Organization } \\
\hline Tom DePonty & AREVA Federal Services \\
\hline Rick Heath & AREVA Federal Services \\
\hline Dave Maloney & CH2M HILL \\
\hline Dan Sowder & Duke Energy \\
\hline Philip O. Moor & High Bridge Associates \\
\hline Humberto E. Garcia & Idaho National Laboratory \\
\hline Richard D. Boardman & Idaho National Laboratory \\
\hline Pat Statwick & JISEA \\
\hline Doug Arent & JISEA \\
\hline Douglas Stewart & Lifeboat Energy \\
\hline Charles Forsberg & Massachusetts Institute of Technology \\
\hline Dana Christensen & NREL \\
\hline Bob Remick & NREL \\
\hline Jeff Bedard & NREL \\
\hline Mark Antkowiak & NREL \\
\hline Mike Helwig & NREL \\
\hline Mark Ruth & NREL \\
\hline Neil Snyder & NREL \\
\hline Jeffrey Bedard & NREL \\
\hline Paul Denholm & NREL \\
\hline Robin Newmark & NREL \\
\hline Susan Hock & NREL \\
\hline Dani Salyer & NREL \\
\hline Scott Gossett & NREL \\
\hline Dan Ingersoll & ORNL \\
\hline Jack Tillman & Sandia National Laboratory \\
\hline Gary E. Rochau & Sandia National Laboratory \\
\hline Joshua Walter & TerraPower \\
\hline David B. Matthews & U.S. Nuclear Regulatory Commission \\
\hline Dennis Miotla & U.S. Department of Energy \\
\hline Ben Cross & U.S. Department of Energy \\
\hline Pete Lyons & U.S. Department of Energy \\
\hline Phillip Bond & White Sands Missile Range \\
\hline Laura Harrington & White Sands Missile Range \\
\hline & \\
\hline & \\
\hline
\end{tabular}




\title{
Appendix B: Workshop Agenda
}

\author{
JISEA
}

\author{
Nuclear and Renewable Energy Synergies Workshop \\ The National Renewable Energy Laboratory Strategic Planning \\ \& the Joint Institute for Strategic Energy Analysis \\ AGENDA
}

Monday \& Tuesday, September 12-13, 2011

RSF San Juan Room 344, NREL, Golden, CO

Workshop Overview:

The workshop is aimed at identifying strategic leveraging opportunities and potential synergies between nuclear energy and renewable energy. Several thought leaders will present specific synergies that they are considering or investigating. All participants will brainstorm other specific synergies in small groups with a focus on identifying specific synergies and prioritizing research and development (R\&D) and analysis projects necessary to put those synergies into practice. A JISEA technical report will summarize the workshop and its findings which may be used to guide funding opportunities.

Monday, September 12, 2011

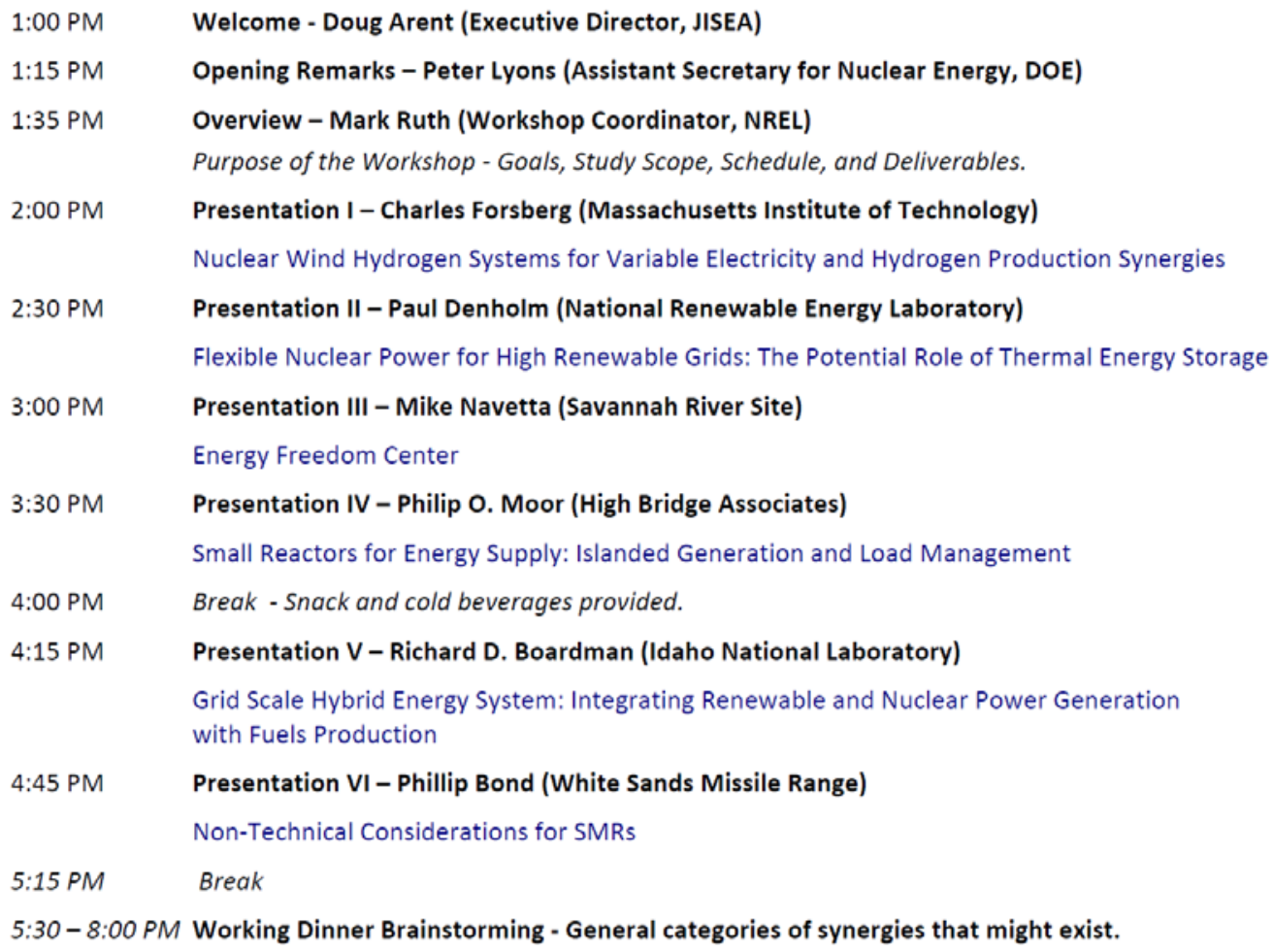


Tuesday, September 13, 2011

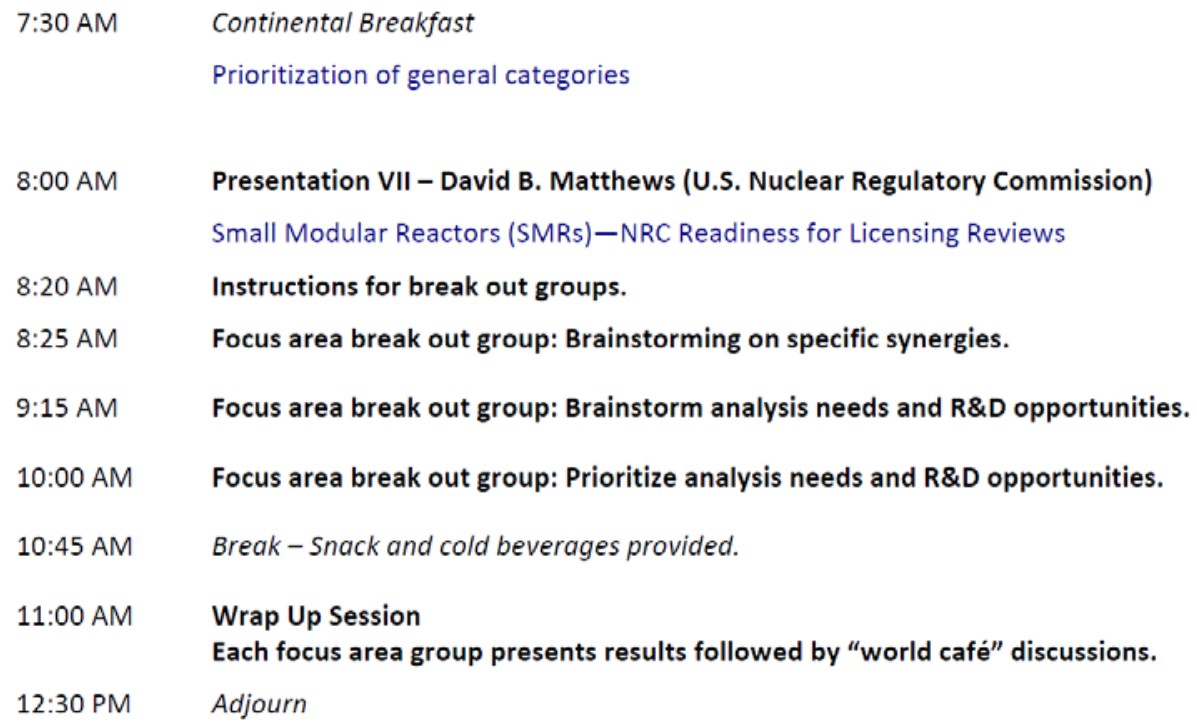




\section{Appendix C: Reading List}

Blue Ribbon Commission on America's Nuclear Future: Draft Report to the Secretary of Energy (July 29, 2011). http://brc.gov/sites/default/files/documents/brc_draft_report_29jul2011_0.pdf

C. W. Forsberg, "Economics of Meeting Peak Electricity Demand Using Hydrogen and Oxygen from Base-Load Nuclear or Off-Peak Electricity," Nuclear Technology, 166, 18-26 April 2009.

C. W. Forsberg, "Nuclear Energy for a Low-Carbon-Dioxide-Emission Transportation System with Liquid Fuels," Nuclear Technology, 164, December 2008.

C. W. Forsberg, Nuclear Energy for Variable Electricity and Liquid Fuels Production:

Integrating Nuclear with Renewables, Fossil Fuels, and Biomass for a Low Carbon World, MITNES-TR-015 (September 2011)

C. W. Forsberg, "Sustainability by Combining Nuclear, Fossil, and Renewable Energy Sources," Progress in Nuclear Energy, 51, 192-200 (2009)

C. Forsberg and G. Haratyk, "Nuclear Wind Hydrogen Systems For Variable Electricity and Hydrogen Production," International Congress on Energy 2011; American Institute of Chemical Engineers Minneapolis, Minnesota; October 16-21, 2011; Paper 234665.

C. Forsberg and M. Kazimi, "Nuclear Hydrogen Using High-Temperature Electrolysis and Light-Water Reactors for Peak Electricity Production," 4th Nuclear Energy Agency Information Exchange Meeting on Nuclear Production of Hydrogen, Oak Brook, Illinois, April 10-16, 2009. http://mit.edu/canes/pdfs/nes-10.pdf

United States Government Accountability Office, Commercial Nuclear Waste: Effects of a Termination of the Yucca Mountain Repository Program and Lessons Learned, GAO-11-229 (April 2011). http://www.gao.gov/new.items/d11229.pdf

G. Haratyk, Nuclear-Renewables Energy System for Hydrogen and Electricity Production, MS Thesis, MIT, June 2011. (C. Forsberg: Thesis Advisor)

G. Haratyk and C. Forsberg, "Integrating Nuclear and Renewables for Hydrogen and Electricity Production”, Paper 1082, Second International Meeting on the Safety and Technology of Nuclear Hydrogen Production, Control, and Management, Embedded American Nuclear Society Topical, San Diego, 15-17 June 2010.

G. Haratyk, C. W. Forsberg, and M. J. Driscoll, Nuclear-Renewables Energy System for Hydrogen and Electricity Production: A Case Study of a Nuclear-Wind-Hydrogen System for the Midwest Electrical Grid, MIT-NES-TR-012 (June 2011).

Y. H. Lee, Conceptual Design of Nuclear-Geothermal Energy Storage System for Variable Electricity Production, MS Thesis, MIT, June 2011 (C. Forsberg: Thesis Advisor)

Y. Lee and C. W. Forsberg, Conceptual Design of Nuclear-Geothermal Energy Storage Systems for Variable Electricity Production, MIT-NES-TR-014 (June 2011). 
Y. H. Lee, C. Forsberg, M. Driscoll, and B. Sapiie, "Options for Nuclear-Geothermal GigawattYear Peak Electricity Storage Systems," Paper 10212, Proc. International Congress on Advanced Nuclear Power Plants, San Diego, 15-17 June 2010.

M. Navetta, U.S. Energy Freedom Center Concept Paper. Savannah River Nuclear Solutions, LLC. (Predecisional Draft).

I. Oloyede, Design and Evaluation of Seasonal Storage Hydrogen Peak Electricity Supply System, MS Thesis, MIT, June 2011 (C. Forsberg: Thesis Advisor)

I. Oloyede and C. Forsberg, "Implications of Gigawatt-Year Electricity Storage Systems on Future Baseload Nuclear Electricity Demand", Paper 10117, Proc. International Congress on Advanced Nuclear Power Plants, San Diego, 15-17 June 2010. 